\title{
Effect of Strain-Temperature History on the Tensile Behavior of Titanium and a Titanium Alloy ${ }^{1}$
}

\author{
Glenn W. Geil and Nesbit L. Carwile
}

\begin{abstract}
This study was made to determine the effect of prestraining specimens in tension under uniaxial and multiaxial stresses at a selected temperature on their tensile behavior at a different temperature. Unnotched and notched cylindrical specimens of initially annealed, commercially pure titanium and initially annealed 4-percent-aluminum, 4-percent-manganese, titanium alloy were extended at selected temperatures to various true strains and then extended to fracture at another temperature. The ductility retained by the prestrained specimens decreased with increase in the prestrain, whereas the strength indices generally were nearly independent of the amount of the prestraining. However, strength indices obtained on some of the deep-notehed specimens of the alloy at $-196^{\circ} \mathrm{C}$ were decreased by prestraining at $+25^{\circ} \mathrm{C}$ as a direct result of the very low retained ductility of the prestrained specimens.
\end{abstract}

\section{Introduction}

The tensile behavior of metals, in general, is affected by their prior thermal and strain-temperature histories. Ripling and Baldwin $[1],{ }^{2}$ in reporting on the phenomenon they called "rheotropic embrittlement" of steel, concluded that a large part of the difference between the ductilities of annealed steels at room temperatures and at low temperatures was rheotropic; that is, the ductility at low temperatures could be improved by prestraining at higher temperatures, at which the ductility of the steel was greater. Similar results were obtained by the present authors [2] for ingot iron, hot-rolled or normalized. However, prestraining annealed ingot iron in tension at room temperature decreased the ductility retained by the specimen at low temperatures.

A recent paper [3] summarized the results obtained in an investigation at the National Bureau of Standards on the effects of low temperatures and multiaxial stresses ${ }^{3}$ on the tensile behavior of an annealed commercially pure titanium. However, as no information was available on the effects of strain temperature history on the tensile properties of titanium or its alloys, a study of these effects was made on unnotched and notched specimens of the initially annealed titanium and on an initially annealed 4-percent-Al, 4-percent-Mn, titanium alloy. The results of this investigation are summarized in the present paper.

\section{Materials and Test Procedures}

\subsection{Materials}

The test specimens were prepared from bars processed from a single heat of commercially pure

${ }_{1}$ This investigation was partially supported by the Materials Laberatory, Directorate of Research, Wright Air Development Center, U. S. A. F., and some of the results were incorporated in WADC Technical Report 56-402 (ASTIA Document No. AD-110 436).

2 Figures in brackets indicate the literature references at the end of this paper. 3 The stress system was varied by changes in the depth of circumferential $60^{\circ} \mathrm{V}$-notches in specimens of circular cross section. titanium (American Society for Testing Materials Designation B265-52T, grade 2) or a single heat of the titanium alloy. The bars were supplied in the form of 1 -in. and $3 / 4$-in. rounds in the hot-rolled and annealed condition. The chemical compositions, other than titanium, of these materials were as follows:

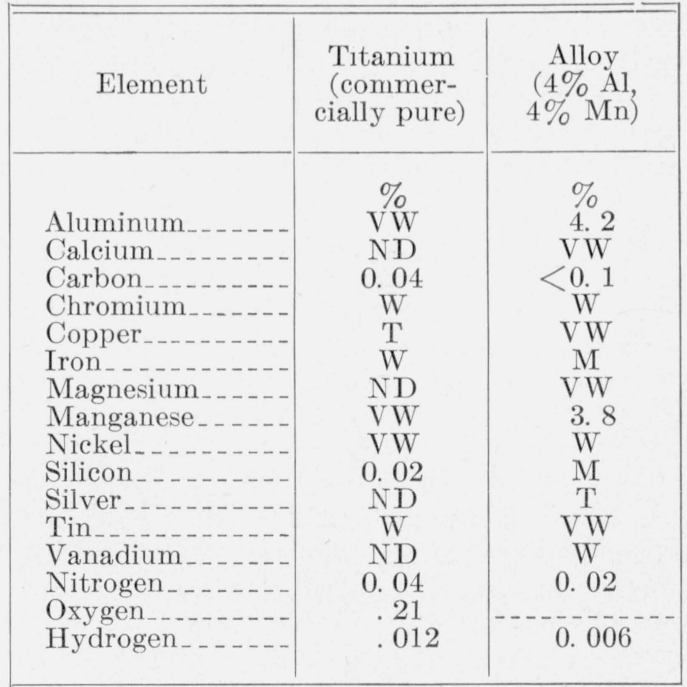

The numerical values are given in percent by weight. The spectrographic analysis determinations are designated by letters. $M$ denotes moderate $(0.1$ to $1.0 \%)$, W denotes weak $(0.01$ to $0.1 \%)$, VW denotes very weak $(0.001$ to $0.01 \%)$, T denotes a trace $(0.0001$ to $0.001 \%)$ and ND denotes not detected.

Both metals were fine-grained; the titanium had a grain size corresponding to American Society for Testing Materials (ASTM) No. 9 and the alloy had a grain size finer than that corresponding to ASTM No. 10. These materials were tested in the asreceived condition (hot-rolled and annealed by the producers). 


\subsection{Specimens}

The specimens were of circular cross section. The unnotched specimens had a 2 -in. reduced section that was gradually tapered from each end; the diameter at the midsection ( 0.400 in.) was about 0.003 in. less than that at the ends. The notched specimens were machined with a circumferential V-notch of $60^{\circ}$ angle having a root radius of 0.05 in. and a constant minimum diameter of $0.35 \mathrm{in}$. at the root of the notch. The notch depth was changed by varying the diameter of the cylindrical portion of the specimen adjacent to the notch. A detailed description of the specimens is given in a previous paper [3].

\subsection{Test Procedures}

A detailed description of the test equipment and the method of maintaining the selected temperature is given in previous publications $[2,4$, and 5]. The tension tests were made in a pendulum hydraulic testing machine on notched and unnotched specimens at a temperature of $+100^{\circ},+25^{\circ}$, or $-196^{\circ} \mathrm{C}$ or at a combination of two of these temperatures. The specimens were extended slowly with the deformation rate maintained at about 0.5 to 1.0 percent contraction in area per minute during the deformation beyond initial yielding. The specimens, except those tested at $+25^{\circ} \mathrm{C}$, were extended while completely immersed in an appropriate bath maintained at the selected temperature. Simultaneous load and diameter measurements (minimum diameter of unnotched specimens, diameter at the base of the notch in the notched specimens) were made throughout each test.

In the normal (single-stage) tension test the specimens were extended to fracture at a selected temperature. Two-stage tension tests were employed to study the effect of prestraining; the specimens were extended at a constant temperature to selected strains and then extended to fracture at a different temperature. Three series of the two-stage tension tests were made. In two series, the specimens were extended in tension at $+25^{\circ} \mathrm{C}$ to selected strains, then the loads were quickly reduced to $200 \mathrm{lb}$ and maintained at this level until the start of the second stage of the tests about $30 \mathrm{~min}$ later. In the second stage, these specimens were extended in tension to fracture at $-196^{\circ}$ or $+100^{\circ} \mathrm{C}$, respectively. During the interval between the two stages of the test, each specimen was maintained at the temperature selected for the second stage. In the other series of two-stage tests, the specimens were extended in tension at $-196^{\circ} \mathrm{C}$ to selected strains, removed from the testing machine, and placed in a liquid nitrogen bath. The testing machine and equipment were brought to a temperature equilibrium at $+25^{\circ} \mathrm{C}$ (requiring a period of approximately $30 \mathrm{~min}$ ). The specimens were then removed from the low temperature bath, warmed in water to $+25^{\circ} \mathrm{C}$, quickly installed in the testing machine, and extended to fracture in the second stage of the test at $+25^{\circ} \mathrm{C}$.

\section{Results and Discussion}

\subsection{Effect of Prestraining Specimens at $+25^{\circ} \mathrm{C}$ on Their Tensile Properties at $-196^{\circ} \mathrm{C}$}

The results of single-stage tests at $-196^{\circ} \mathrm{C}$ and two-stage tests at $+25^{\circ}$ and $-196^{\circ} \mathrm{C}$, respectively, on unnotched and notched specimens of the initially annealed titanium and titanium alloy are summarized in table 1 .

\section{a. True Stress Versus True Strain Curves}

The true stress ${ }^{4}$ versus true strain ${ }^{5}$ curves for the unnotched specimens are shown in figures 1 and 2 and those for notched specimens with notch depths ${ }^{6}$

4 True stress was determined by dividing the current load by the current minimum cross-sectional area of the specimen

5 True strain is expressed as the natural logarithm of the ratio of the original minimum cross-sectional area of the specimen, $A_{0}$, to the current minimum cross sectional area, A.

${ }^{6}$ Notch depth is expressed as the percent of cross-sectional area removed in machining the notch in the specimen.

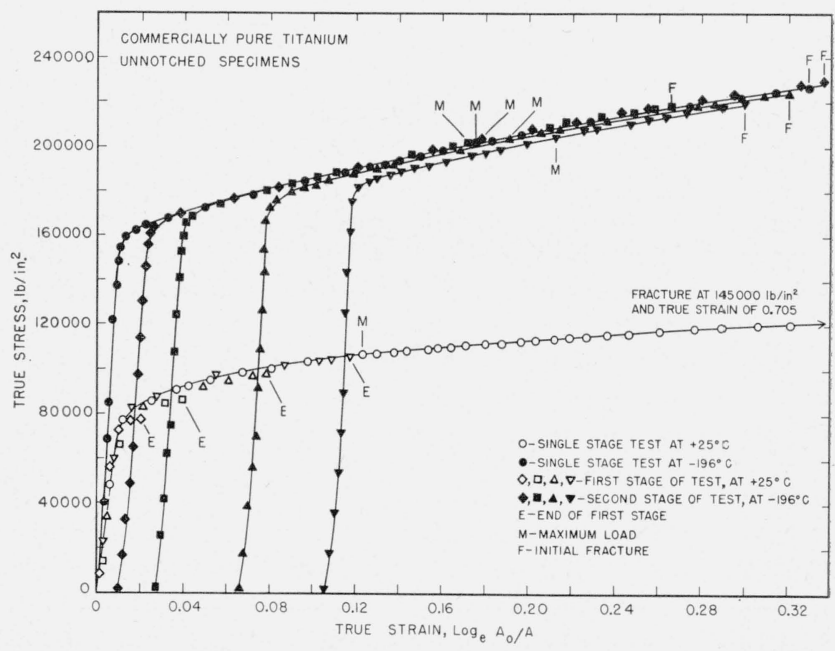

FIGURE 1. True stress-true strain relations obtained in singleand two-stage tension tests at $+25^{\circ}$ and $-196^{\circ} \mathrm{C}$ on unnotched specimens of initially annealed commercially pure titanium.

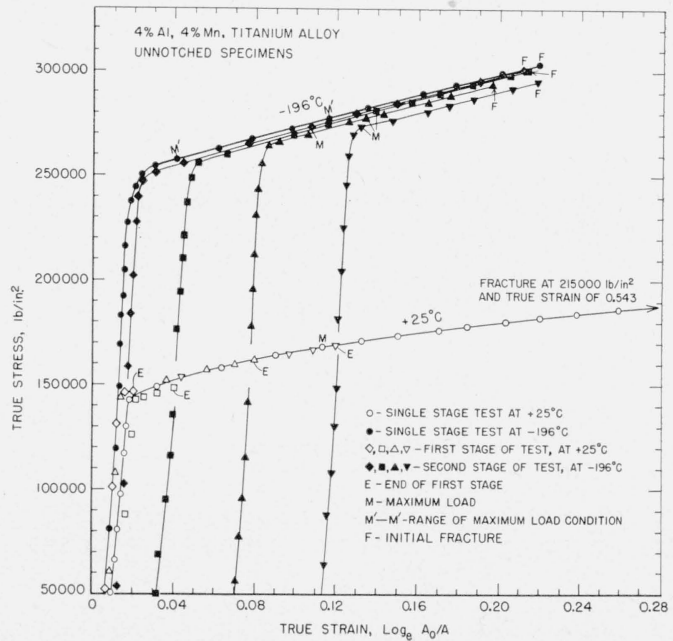

FIguRE 2. True stress-true strain relations obtained in singleand two-stage tension tests at $+25^{\circ}$ and $-196^{\circ} C$ on unnotched specimens of initially annealed 4-percent-Al, 4-percent-Mn titanium alloy. 
TABLE 1. Tensile properties of unnotched and notched $\left(60^{\circ}\right.$ notch angle, 0.05 in. root radius) specimens tested in single stage at $-196^{\circ} \mathrm{C}$ and in two stages at $+25^{\circ}$ and $-196^{\circ} \mathrm{C}$, respectively

\begin{tabular}{|c|c|c|c|c|c|c|c|c|c|c|c|c|c|c|c|}
\hline \multirow{3}{*}{$\begin{array}{l}\text { Notch } \\
\text { depth }\end{array}$} & \multirow{3}{*}{$D$ a } & \multirow{3}{*}{$d^{\mathrm{b}}$} & \multirow{3}{*}{$\begin{array}{c}\text { Stress } \\
\text { con- } \\
\text { cen- } \\
\text { tra- } \\
\text { tion } \\
\text { factor, } \\
K_{t}\end{array}$} & \multirow{3}{*}{$\begin{array}{c}\text { Triaxi- } \\
\text { ality, } \\
S_{t} / S_{t}\end{array}$} & \multicolumn{2}{|c|}{$\begin{array}{l}\text { First stage of test, } \\
+25^{\circ} \mathrm{C}\end{array}$} & \multicolumn{7}{|c|}{ Second stage of test, $-196^{\circ} \mathrm{C}$} & \multirow{3}{*}{$\begin{array}{l}\text { Reduc- } \\
\text { tion of } \\
\text { area }\end{array}$} & \multirow{3}{*}{$\begin{array}{l}\text { Elonga- } \\
\text { tion } f \\
\text { in } 2 \text { in. }\end{array}$} \\
\hline & & & & & \multirow{2}{*}{$\begin{array}{l}\text { True } \\
\text { strain d } \\
\text { at end } \\
\text { of stage }\end{array}$} & \multirow{2}{*}{$\begin{array}{c}\text { True stress } \\
\text { at end } \\
\text { of stage }\end{array}$} & \multirow{2}{*}{$\begin{array}{l}\text { Tensile e } \\
\text { strength } \\
\text { or notch } \\
\text { strength }\end{array}$} & \multicolumn{2}{|c|}{ True stress } & \multicolumn{2}{|c|}{ Total true strain ${ }^{\mathrm{d}}$} & \multicolumn{2}{|c|}{$\begin{array}{l}\text { Retained true } \\
\text { strain }\end{array}$} & & \\
\hline & & & & & & & & $\begin{array}{l}\text { at maxi- } \\
\text { mum load }\end{array}$ & $\begin{array}{l}\text { at initial } \\
\text { fracture }\end{array}$ & $\underset{\text { mum }}{\text { at maxi }}$ & $\begin{array}{l}\text { at ini- } \\
\text { tial } \\
\text { fracture }\end{array}$ & $\underset{\text { mum }}{\text { at maxi- }}$ & $\begin{array}{c}\text { at ini- } \\
\text { tial } \\
\text { fracture }\end{array}$ & & \\
\hline
\end{tabular}

Commercially pure titanium

\begin{tabular}{|c|c|c|c|c|c|c|c|c|c|c|c|c|c|c|c|}
\hline $\begin{array}{c}\% \\
0 \mathrm{~g} \\
0 \\
0 \\
0 \\
0\end{array}$ & in. & $\begin{array}{l}i n . \\
0.400 \\
.400 \\
.400 \\
.400 \\
.400\end{array}$ & $\begin{array}{l}1.00 \\
1.00 \\
1.00 \\
1.00 \\
1.00\end{array}$ & $\begin{array}{l}0.00 \\
.00 \\
.00 \\
.00 \\
.00\end{array}$ & $\begin{array}{l}0 \\
.020 \\
.039 \\
.078 \\
.118\end{array}$ & $\begin{array}{r}l b / \text { in. }^{2} \\
0 \\
77,000 \\
86,000 \\
97.000 \\
106.000\end{array}$ & $\begin{array}{l}\text { lb/in. }{ }^{2} \\
169,000 \\
170,000 \\
170,000 \\
168,000 \\
165,000\end{array}$ & $\begin{array}{l}l b / \text { in }^{2} \\
200,000 \\
203,000 \\
203,000 \\
203,000 \\
204,000\end{array}$ & $\begin{array}{l}l b / \text { in. }{ }^{2} \\
228,000 \\
229,000 \\
218,000 \\
223,000 \\
219,000\end{array}$ & $\begin{array}{r}0.167 \\
.178 \\
.177 \\
.191 \\
.212\end{array}$ & $\begin{array}{r}0.330 \\
.336 \\
.266 \\
.321 \\
.300\end{array}$ & $\begin{array}{r}0.167 \\
.158 \\
.138 \\
.113 \\
.094\end{array}$ & $\begin{array}{r}0.330 \\
.316 \\
.227 \\
.243 \\
.182\end{array}$ & $\begin{array}{c}\% \\
30 \\
30 \\
22 \\
28 \\
25\end{array}$ & $\begin{array}{c}\% \\
21 \\
18 \\
18 \\
17 \\
17\end{array}$ \\
\hline $\begin{array}{l}10 \\
10 \\
10 \\
10 \\
10\end{array}$ & $\begin{array}{l}0.370 \\
.370 \\
.370 \\
.370 \\
.370\end{array}$ & $\begin{array}{l}.350 \\
.350 \\
.350 \\
.350 \\
.350\end{array}$ & $\begin{array}{l}1.7 \\
1.7 \\
1.7 \\
1.7 \\
1.7\end{array}$ & $\begin{array}{l}.08 \\
.08 \\
.08 \\
.08 \\
.08\end{array}$ & $\begin{array}{l}0 \\
.020 \\
.040 \\
.080 \\
.111\end{array}$ & $\begin{array}{r}0 \\
85,000 \\
96,000 \\
103,000 \\
113,000\end{array}$ & $\begin{array}{l}183,000 \\
181,000 \\
181,000 \\
181,000 \\
180,000\end{array}$ & $\begin{array}{l}\text { (h) } \\
\text { (h) } \\
\text { (h) } \\
\text { (h) } \\
\text { (h) }\end{array}$ & $\begin{array}{l}199,000 \\
198,000 \\
199,000 \\
207,000 \\
209,000\end{array}$ & 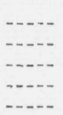 & $\begin{array}{l}.081 \\
.087 \\
.093 \\
.132 \\
.144\end{array}$ & 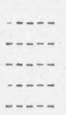 & $\begin{array}{l}.081 \\
.067 \\
.053 \\
.052 \\
.033\end{array}$ & $\begin{array}{r}8 \\
8 \\
9 \\
13 \\
14\end{array}$ & $-\cdots$ \\
\hline $\begin{array}{l}30 \\
30 \\
30 \\
30 \\
30\end{array}$ & $\begin{array}{l}.418 \\
.418 \\
.418 \\
.418 \\
.418\end{array}$ & $\begin{array}{l}.350 \\
.350 \\
.350 \\
.350 \\
.350\end{array}$ & $\begin{array}{l}1.9 \\
1.9 \\
1.9 \\
1.9 \\
1.9\end{array}$ & $\begin{array}{l}.23 \\
.23 \\
.23 \\
.23 \\
.23\end{array}$ & $\begin{array}{l}0 \\
.020 \\
.041 \\
.080 \\
.121\end{array}$ & $\begin{array}{r}0 \\
100,000 \\
116,000 \\
123,000 \\
133,000\end{array}$ & $\begin{array}{l}213,000 \\
213,000 \\
215,000 \\
212,000 \\
209,000\end{array}$ & $\begin{array}{l}\text { (h) } \\
\text { (h) } \\
\text { (h) } \\
\text { (h) } \\
\text { (h) }\end{array}$ & $\begin{array}{l}221,000 \\
224,000 \\
230,000 \\
237,000 \\
239,000\end{array}$ & 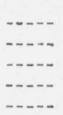 & $\begin{array}{l}.039 \\
.049 \\
.064 \\
.110 \\
.134\end{array}$ & $\begin{array}{l}-\cdots \\
-\cdots- \\
-\cdots- \\
-\cdots-\end{array}$ & $\begin{array}{l}.039 \\
.029 \\
.023 \\
.030 \\
.013\end{array}$ & $\begin{array}{r}5 \\
5 \\
7 \\
10 \\
13\end{array}$ & - \\
\hline $\begin{array}{l}50 \mathrm{~g} \\
50 \\
50 \\
50 \\
50\end{array}$ & $\begin{array}{l}.495 \\
.495 \\
.495 \\
.495 \\
.495\end{array}$ & $\begin{array}{l}.350 \\
.350 \\
.350 \\
.350 \\
.350\end{array}$ & $\begin{array}{l}2.0 \\
2.0 \\
2.0 \\
2.0 \\
2.0\end{array}$ & $\begin{array}{l}.33 \\
.33 \\
.33 \\
.33 \\
.33\end{array}$ & $\begin{array}{l}0 \\
.021 \\
.041 \\
.080 \\
.121\end{array}$ & $\begin{array}{r}0 \\
115,000 \\
135,000 \\
149,000 \\
160,000\end{array}$ & $\begin{array}{l}246,000 \\
244,000 \\
247,000 \\
244,000 \\
240,000\end{array}$ & $\begin{array}{l}\text { (h) } \\
\text { (h) } \\
\text { (h) } \\
\text { (h) } \\
\text { (h) }\end{array}$ & $\begin{array}{l}259,000 \\
257,000 \\
266,000 \\
272,000 \\
279,000\end{array}$ & $\begin{array}{l}-\cdots- \\
-\cdots \\
-\cdots- \\
-\cdots\end{array}$ & $\begin{array}{l}.054 \\
.049 \\
.071 \\
.106 \\
.145\end{array}$ & 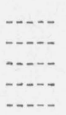 & $\begin{array}{l}.054 \\
.028 \\
.030 \\
.026 \\
.024\end{array}$ & $\begin{array}{r}5 \\
5 \\
8 \\
11 \\
14\end{array}$ & בי \\
\hline $\begin{array}{l}70 \\
70 \\
70 \\
70 \\
70 \\
70\end{array}$ & $\begin{array}{r}.639 \\
.639 \\
.639 \\
.639 \\
.639 \\
.639\end{array}$ & $\begin{array}{l}.350 \\
.350 \\
.350 \\
.350 \\
.350 \\
.350\end{array}$ & $\begin{array}{l}2.1 \\
2.1 \\
2.1 \\
2.1 \\
2.1 \\
2.1\end{array}$ & $\begin{array}{l}.39 \\
.39 \\
.39 \\
.39 \\
.39 \\
.39\end{array}$ & $\begin{array}{l}0 \\
.022 \\
.041 \\
.080 \\
.082 \\
.120\end{array}$ & $\begin{array}{r}0 \\
128,000 \\
137,000 \\
167,000 \\
168,000 \\
177,000\end{array}$ & $\begin{array}{l}258,000 \\
253.000 \\
256,000 \\
258,000 \\
262,000 \\
253,000\end{array}$ & $\begin{array}{l}\text { (h) } \\
\text { (h) } \\
\text { (b) } \\
\text { (h) } \\
\text { (b) } \\
\text { (h) }\end{array}$ & $\begin{array}{l}270,000 \\
267,000 \\
273,000 \\
286,000 \\
291,000 \\
293,000\end{array}$ & 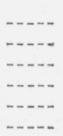 & $\begin{array}{l}.046 \\
.047 \\
.060 \\
.098 \\
.102 \\
.142\end{array}$ & 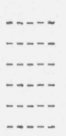 & $\begin{array}{l}.046 \\
.025 \\
.019 \\
.018 \\
.020 \\
.022\end{array}$ & $\begin{array}{r}5 \\
5 \\
5 \\
10 \\
10 \\
13\end{array}$ & $\begin{array}{l}-.- \\
-\cdots \\
-\cdots \\
-\cdots\end{array}$ \\
\hline $87 \mathrm{~g}$ & .990 & .350 & 2.1 & .41 & 0 & 0 & 257,000 & (b) & 265,000 & $\ldots$ & .034 & .... & .034 & 4 & -... \\
\hline
\end{tabular}

4-percent-Al, 4-percent-Mn, titanium alloy

\begin{tabular}{|c|c|c|c|c|c|c|c|c|c|c|c|c|c|c|c|}
\hline $\begin{array}{l}0 \mathrm{~g} \\
0 \\
0 \\
0 \\
0 \\
0\end{array}$ & 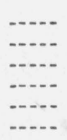 & $\begin{array}{r}0.400 \\
.400 \\
.400 \\
.400 \\
.400 \\
.400\end{array}$ & $\begin{array}{l}1.0 \\
1.0 \\
1.0 \\
1.0 \\
1.0 \\
1.0\end{array}$ & $\begin{array}{l}0.00 \\
.00 \\
.00 \\
.00 \\
.00 \\
.00\end{array}$ & $\begin{array}{l}0 \\
.021 \\
.020 \\
.040 \\
.080 \\
.120\end{array}$ & $\begin{array}{r}0 \\
145,000 \\
146,000 \\
148,000 \\
162,000 \\
169,000\end{array}$ & $\begin{array}{l}246,000 \\
246,000 \\
246,000 \\
245,000 \\
243,000 \\
240,000\end{array}$ & $\begin{array}{l}278,000 \\
279,000 \\
274,000 \\
281,000 \\
278,000 \\
274,000\end{array}$ & $\begin{array}{l}298,000 \\
292,000 \\
308,000 \\
300,000 \\
294,000 \\
295,000\end{array}$ & $\begin{array}{r}0.122 \\
.129 \\
.112 \\
.130 \\
.134 \\
.132\end{array}$ & $\begin{array}{r}0.213 \\
.173 \\
.251 \\
.214 \\
.196 \\
.219\end{array}$ & $\begin{array}{r}0.122 \\
.108 \\
.092 \\
.090 \\
.054 \\
.012\end{array}$ & $\begin{array}{l}0.213 \\
.152 \\
.231 \\
.174 \\
.116 \\
.099\end{array}$ & $\begin{array}{l}19 \\
16 \\
22 \\
18 \\
17 \\
18\end{array}$ & $\begin{array}{r}7 \\
-8 \\
8 \\
9 \\
11\end{array}$ \\
\hline $\begin{array}{l}10 \\
10 \\
10 \\
10 \\
10\end{array}$ & $\begin{array}{l}.370 \\
.370 \\
.370 \\
.370 \\
.370\end{array}$ & $\begin{array}{l}.350 \\
.350 \\
.350 \\
.350 \\
.350\end{array}$ & $\begin{array}{l}1.7 \\
1.7 \\
1.7 \\
1.7 \\
1.7\end{array}$ & $\begin{array}{l}.08 \\
.08 \\
.08 \\
.08 \\
.08\end{array}$ & $\begin{array}{l}0 \\
.020 \\
.039 \\
.058 \\
.078\end{array}$ & $\begin{array}{r}0 \\
158,000 \\
159,000 \\
168,000 \\
173,000\end{array}$ & $\begin{array}{l}268,000 \\
266,000 \\
264,000 \\
263,000 \\
261,000\end{array}$ & $\begin{array}{l}\text { (h) } \\
\text { (h) } \\
\text { (h) } \\
\text { (h) } \\
\text { (h) }\end{array}$ & $\begin{array}{l}288,000 \\
288,000 \\
288,000 \\
283.000 \\
286,000\end{array}$ & $\begin{array}{l}-\cdots . \\
-\cdots- \\
-\cdots- \\
-\cdots- \\
-\cdots\end{array}$ & $\begin{array}{l}.070 \\
.076 \\
.084 \\
.077 \\
.088\end{array}$ & 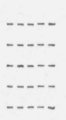 & $\begin{array}{l}.070 \\
.056 \\
.045 \\
.019 \\
.010\end{array}$ & $\begin{array}{l}8 \\
9 \\
7 \\
9 \\
9\end{array}$ & $\begin{array}{l}\cdots-- \\
\cdots- \\
\cdots-\end{array}$ \\
\hline $\begin{array}{l}30 \\
30 \\
30 \\
30 \\
30\end{array}$ & $\begin{array}{l}.418 \\
.418 \\
.418 \\
.418 \\
.418\end{array}$ & $\begin{array}{l}.350 \\
.350 \\
.350 \\
.350 \\
.350\end{array}$ & $\begin{array}{l}1.9 \\
1.9 \\
1.9 \\
1.9 \\
1.9\end{array}$ & $\begin{array}{l}.23 \\
.23 \\
.23 \\
.23 \\
.23\end{array}$ & $\begin{array}{l}0 \\
.020 \\
.043 \\
.060 \\
.079\end{array}$ & $\begin{array}{r}0 \\
181,000 \\
195,000 \\
211,000 \\
206,000\end{array}$ & $\begin{array}{l}307,000 \\
307,000 \\
304,000 \\
300,000 \\
277,000\end{array}$ & $\begin{array}{l}\text { (h) } \\
\text { (h) } \\
\text { (h) } \\
\text { (h) } \\
\text { (h) }\end{array}$ & $\begin{array}{l}317,000 \\
320,000 \\
323,000 \\
322,000 \\
302,000\end{array}$ & $\begin{array}{l}-\cdots \\
-\cdots- \\
-\cdots- \\
-\cdots\end{array}$ & $\begin{array}{l}.032 \\
.038 \\
.057 \\
.067 \\
.083\end{array}$ & ב... & $\begin{array}{l}.032 \\
.018 \\
.014 \\
.007 \\
.004\end{array}$ & $\begin{array}{l}4 \\
4 \\
5 \\
5 \\
9\end{array}$ & 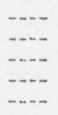 \\
\hline $\begin{array}{l}50 \mathrm{~g} \\
50 \\
50 \\
50 \\
50\end{array}$ & $\begin{array}{l}.495 \\
.495 \\
.495 \\
.495 \\
.495\end{array}$ & $\begin{array}{l}.350 \\
.350 \\
.350 \\
.350 \\
.350\end{array}$ & $\begin{array}{l}2.0 \\
2.0 \\
2.0 \\
2.0 \\
2.0\end{array}$ & $\begin{array}{l}.33 \\
.33 \\
.33 \\
.33 \\
.33\end{array}$ & $\begin{array}{l}0 \\
.021 \\
.040 \\
.062 \\
.081\end{array}$ & $\begin{array}{r}0 \\
200,000 \\
223,000 \\
238,000 \\
251,000\end{array}$ & $\begin{array}{l}325,000 \\
331,000 \\
337,000 \\
317,000 \\
207,000\end{array}$ & $\begin{array}{l}\text { (h) } \\
\text { (h) } \\
\text { (h) } \\
\text { )h( } \\
\text { (h) }\end{array}$ & $\begin{array}{l}334,000 \\
342,000 \\
354,000 \\
339,000 \\
225,000\end{array}$ & 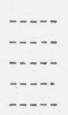 & $\begin{array}{l}.026 \\
.033 \\
.049 \\
.064 \\
.081\end{array}$ & $\begin{array}{l}-\ldots \\
-\cdots \\
-\cdots \\
-\cdots\end{array}$ & $\begin{array}{l}.026 \\
.012 \\
.009 \\
.002 \\
.000\end{array}$ & $\begin{array}{l}3 \\
4 \\
5 \\
6 \\
7\end{array}$ & $\begin{array}{l}-\cdots \\
\cdots-1 \\
\cdots-1 \\
\cdots-\end{array}$ \\
\hline $\begin{array}{l}70 \\
70 \\
70 \\
70 \\
70\end{array}$ & $\begin{array}{l}.639 \\
.639 \\
.639 \\
.639 \\
.639\end{array}$ & $\begin{array}{l}.350 \\
.350 \\
.350 \\
.350 \\
.350\end{array}$ & $\begin{array}{l}2.1 \\
2.1 \\
2.1 \\
2.1 \\
2.1\end{array}$ & $\begin{array}{l}.39 \\
.39 \\
.39 \\
.39 \\
.39\end{array}$ & $\begin{array}{l}0 \\
.019 \\
.040 \\
.059 \\
.080\end{array}$ & $\begin{array}{r}0 \\
202,000 \\
239,000 \\
255,000 \\
271,000\end{array}$ & $\begin{array}{l}337,000 \\
336,000 \\
318,000 \\
311,000 \\
276,000\end{array}$ & $\begin{array}{l}\text { (h) } \\
(\mathrm{h}) \\
(\mathrm{h}) \\
(\mathrm{h}) \\
(\mathrm{h})\end{array}$ & $\begin{array}{l}345,000 \\
346,000 \\
331,000 \\
331,000 \\
276,000\end{array}$ & 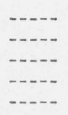 & $\begin{array}{l}.024 \\
.026 \\
.038 \\
.060 \\
.079\end{array}$ & 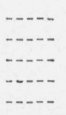 & $\begin{array}{l}.024 \\
.007 \\
.000 \\
.001 \\
.000\end{array}$ & $\begin{array}{l}3 \\
4 \\
4 \\
5 \\
6\end{array}$ & 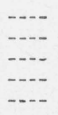 \\
\hline 87 & .990 & .350 & 2.1 & .41 & 0 & 0 & 337,000 & (h) & 341,000 & $\ldots$ & .012 & $\ldots$ & .012 & 3 & $-\cdots$ \\
\hline
\end{tabular}

a Diameter of cylindrical portion of the specimen adjacent to the notch.

b Minimum diameter of unnotched specimen or diameter of notched specimen at the base of the notch.

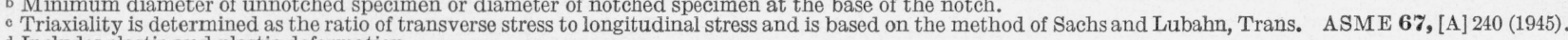

d Includes elastic and plastic deformation.

- Determined by dividing the highest load attained at $-196^{\circ} \mathrm{C}$ by the original minimum cross-sectional area

f Measurements based on punch marks in fillets. Specimens had a reduced section of $2.0 \mathrm{in}$. length.

g Tensile values are the average for 2 or more specimens.

h Fractured before the slope of the load-extension curve became zero. 


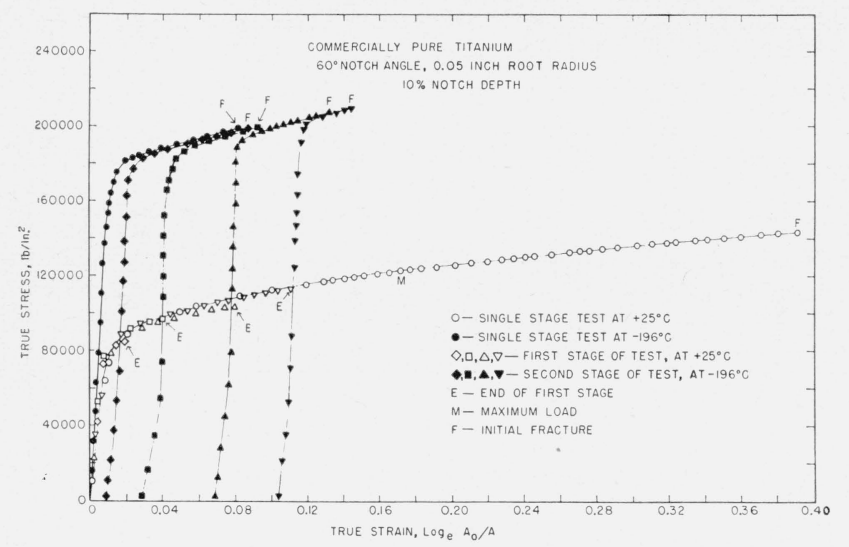

Figure 3. True stress-true strain relations obtained in singleand two-stage tension tests at $+25^{\circ}$ and $-196^{\circ} \mathrm{C}$ on notched specimens $(10 \%$ notch depth) of the titanium.

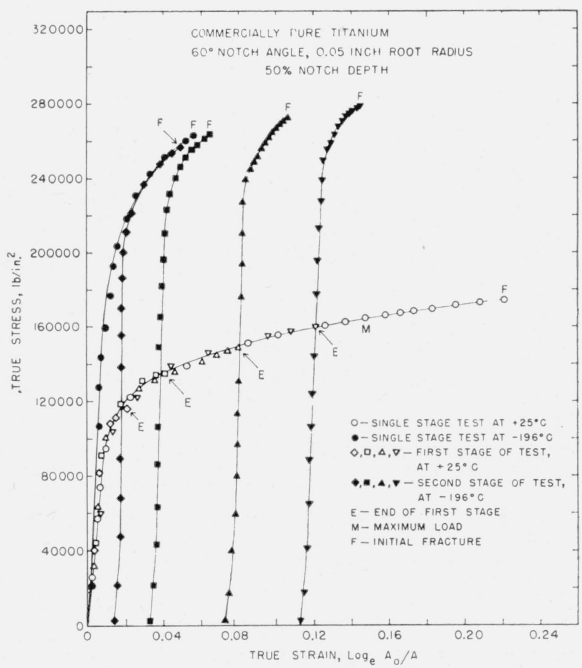

FIGURE 4. True stress-true strain relations obtained in singleand two-stage tension tests at $+25^{\circ}$ and $-196^{\circ} \mathrm{C}$ on notched specimens $(50 \%$ notch depth) of the titanium.

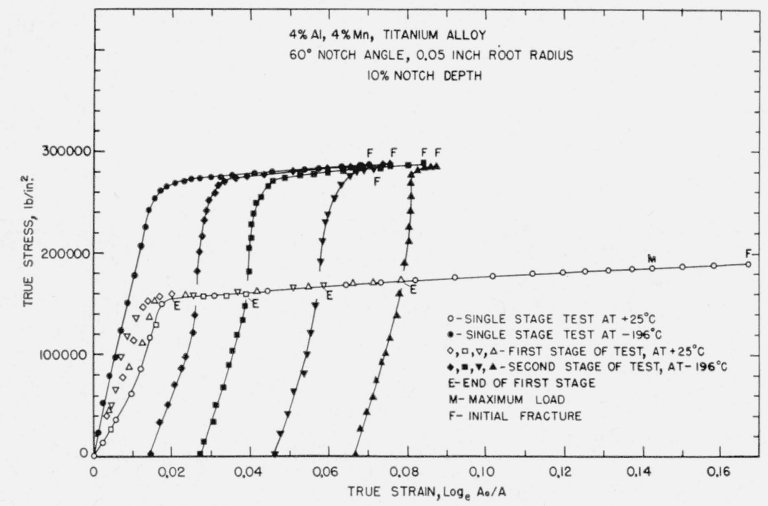

FIGURE 5. True stress-true strain relations obtained in singleand two-stage tension tests at $+25^{\circ}$ and $-196^{\circ} \mathrm{C}$ on notched specimens (10\% notch depth) of the alloy.

of 10 and 50 percent are shown in figures 3 to 6 . For brevity, the true stress-true strain curves for the twostage tests on specimens with notch depths of 30 and 70 percent are not shown; the forms of these curves were generally similar to those for the specimens with a notch depth of 50 percent.

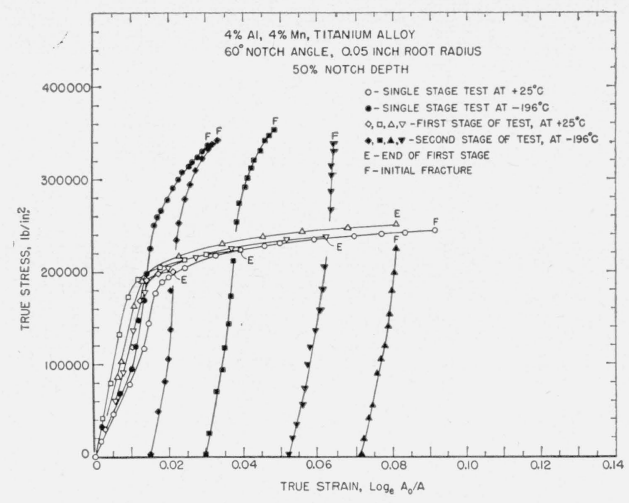

FIGURE 6. True stress-true strain relations obtained in singleand two-stage tension tests at $+25^{\circ}$ and $-196^{\circ} \mathrm{C}$ on notched specimens (50\% notch depth) of the alloy.

The portion of the true stress-true strain curves (figs. 1 and 2) for the second stage of the tests with the unnotched specimens of each material at $-196^{\circ}$ $\mathrm{C}$ lie near or only slightly below those representing single-stage tests of the same material at $-196^{\circ} \mathrm{C}$; the lowering of the curves, in general, tends to increase with increase in the prestrain of the specimens at $+25^{\circ} \mathrm{C}$. A similar trend is indicated in the curves for the notched specimens with a depth of 10 percent (figs. 3 and 5). The ductility of the notched specimens with depths of 30 percent or greater was insufficient at $-196^{\circ} \mathrm{C}$ to make this comparison of the curves. These true stress-true strain data indicate that the total work hardening (strain hardening and strain aging or recovery) during the prestraining of specimens at $+25^{\circ} \mathrm{C}$ is nearly the same as the total work hardening (mainly strain hardening) of corresponding specimens extended to the same strains at $-196^{\circ} \mathrm{C}$. If any strain aging occurred during the interval of approximately $30 \mathrm{~min}$ between the two stages of these tests, it was limited to a very small value as the specimens were maintained at $-196^{\circ} \mathrm{C}$ during this interval.

$$
\text { b. Strength at }-196^{\circ} \mathrm{C}
$$

The effects of prestraining unnotched and notched specimens to true strains up to 0.08 or 0.12 at $+25^{\circ} \mathrm{C}$ on their strength indices at $-196^{\circ} \mathrm{C}$ are shown in figures 7 and 8 . At $-196^{\circ} \mathrm{C}$, the tensile strength, ${ }^{7}$ true stress at maximum load, and true stress at initial fracture ${ }^{8}$ of the unnotched specimens of each material were nearly independent of the prestraining at $+25^{\circ} \mathrm{C}$.

The data obtained in the two-stage tests on the notched specimens exhibit a general trend of an independence of the strength indices at $-196^{\circ} \mathrm{C}$ on the prestraining at $+25^{\circ} \mathrm{C}$. This trend was observed for all of the notched specimens of the commercially pure titanium (fig. 7) and for the alloy specimens with a notch depth of 10 percent (fig. 8). However, a relatively large decrease was observed

7 Tensile- and notch-strength values obtained for a specimen in the second stage of the test are based on the minimum cross-sectional area of the specimen prior to the prestraining.

${ }^{8}$ Initial fracture, as used in this paper, designates the beginning of the very rapid propagation of the main fracture crack across the specimen. The true stress and true strain values at initial fracture are based on diameter measurements made immediately preceding the fracture. 

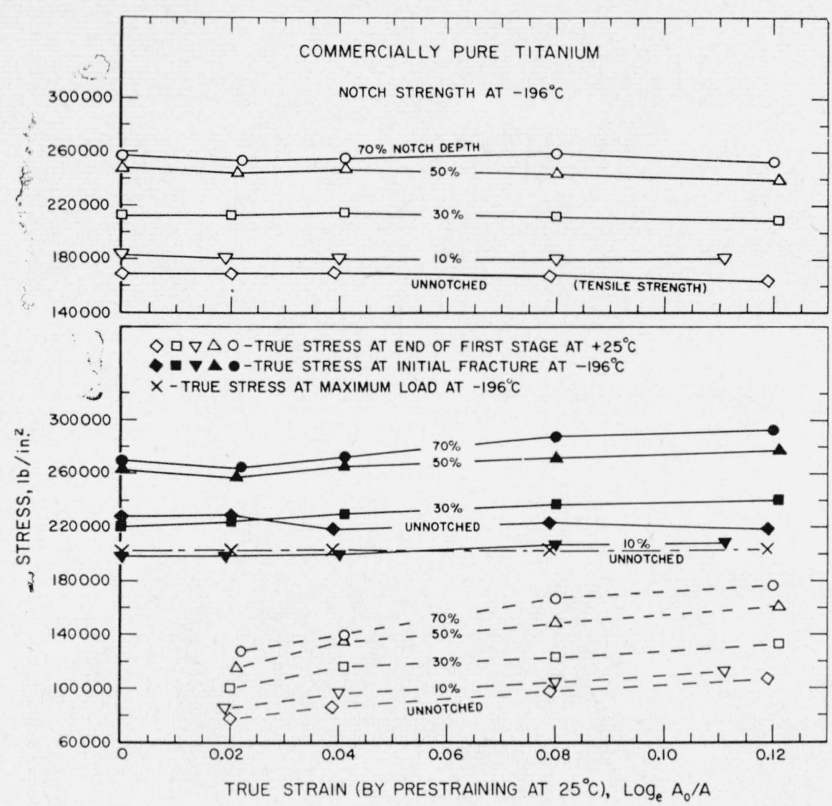

FIGURE 7. Effect of prestraining in tension at $+25^{\circ} \mathrm{C}$ on the strength at $-196^{\circ} \mathrm{C}$ of unnotched and notched specimens of the titanium.

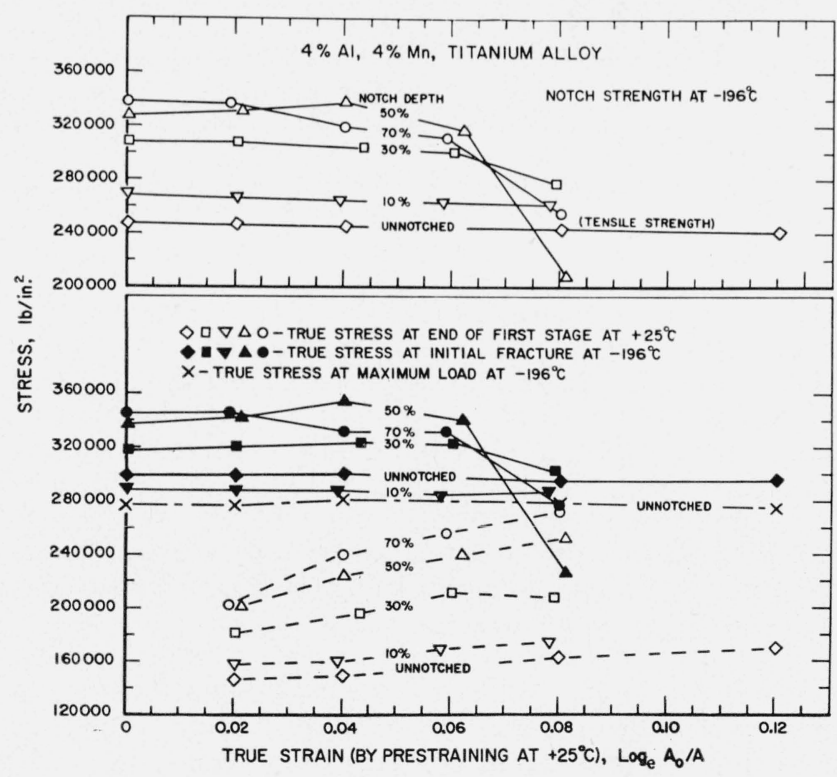

Figure 8. Effect of prestraining in tension at $+25^{\circ} \mathrm{C}$ on the strength at $-196^{\circ} \mathrm{C}$ of unnotched and notched specimens of the alloy.

in the values of notch strength (see footnote 7) and true stress at initial fracture of the alloy specimens with 30-, 50-, and 70-percent notch depths that were prestrained to a true strain of 0.08 . This decrease can be attributed directly to the low ductility of these specimens in the second stage of the test at $-196^{\circ} \mathrm{C}$; these specimens fractured during the loading in the elastic deformation range.
The ductility of all the notched specimens at $-196^{\circ} \mathrm{C}$ was quite limited as evidenced by the fractures that occurred while the loads were increasing; i. e., before normal maximum load conditions ${ }^{9}$ were attained. However, in the limited sense that the loads at fracture were the highest loads on the specimens at $-196^{\circ} \mathrm{C}$, the values of the true stresses at initial fracture may also be considered as true stresses at maximum load.

\section{c. Ductility}

The effects of prestraining unnotched and notched specimens of the titanium and the alloy to selected true strains up to 0.08 or 0.12 at $+25^{\circ} \mathrm{C}$ on their ductility at $-196^{\circ} \mathrm{C}$ are summarized in figures 9 and 10. The "total true strain" values reported for the second stage of the test at $-196^{\circ} \mathrm{C}$ include the true strain at the end of the first stage of the test at $+25^{\circ}$ C. The "retained true strain" values include only the additional true strain during the second stage of the test.

The total true strain at maximum load of unnotched specimens at $-196^{\circ} \mathrm{C}$ increased slightly with increase in prestrain of the titanium, especially in the range 0.04 to 0.12 (fig. 9), whereas it was nearly constant and independent of the prestrain for the alloy (fig. 10). The retained true strains at maximum load of the unnotched specimens of both metals at $-196^{\circ} \mathrm{C}$ decreased with increase in the prestrain by an amount approximately equal to (alloy specimens) or slighly less than (titanium specimens) the prestrain.

The total true strain at initial fracture of the unnotched specimens of both metals at $-196^{\circ} \mathrm{C}$ was nearly independent of the prestrain at $+25^{\circ} \mathrm{C}$ and thus the retained true strains at initial fracture of these specimens were decreased by an amount approximately equal to the prestrain.

The unnotched specimen of titanium that was prestrained at $25^{\circ} \mathrm{C}$ to a true strain of 0.039 broke apparently prematurely in the second stage of the test at $-196^{\circ} \mathrm{C}$; the fracture occurred in the shoulder portion of the necked section and not at the minimum cross-sectional area. Thus, the value obtained for the total true strain at initial fracture (table 1) was not truly representative for this degree of prestrain and it is not included in the plotted points of figure 9. Moreover, the value obtained for the true stress at initial fracture of this specimen (fig. 7) is slightly low due to the premature fracture.

As mentioned previously, the notched specimens did not retain sufficient ductility at $-196^{\circ} \mathrm{C}$ to attain a normal maximum load condition. The true strains at initial fracture of the notched specimens that were extended in single-stage tension tests at $-196^{\circ} \mathrm{C}$ were also very small, especially for specimens with a notch depth of 30 percent or greater.

Prestraining in tension at $+25^{\circ} \mathrm{C}$ generally increased the total true strain at initial fracture of

\footnotetext{
${ }^{9}$ In this paper a normal maximum load condition is considered as that condition at which the slope of the load-extension curve becomes zero beyond the region of yielding.
} 


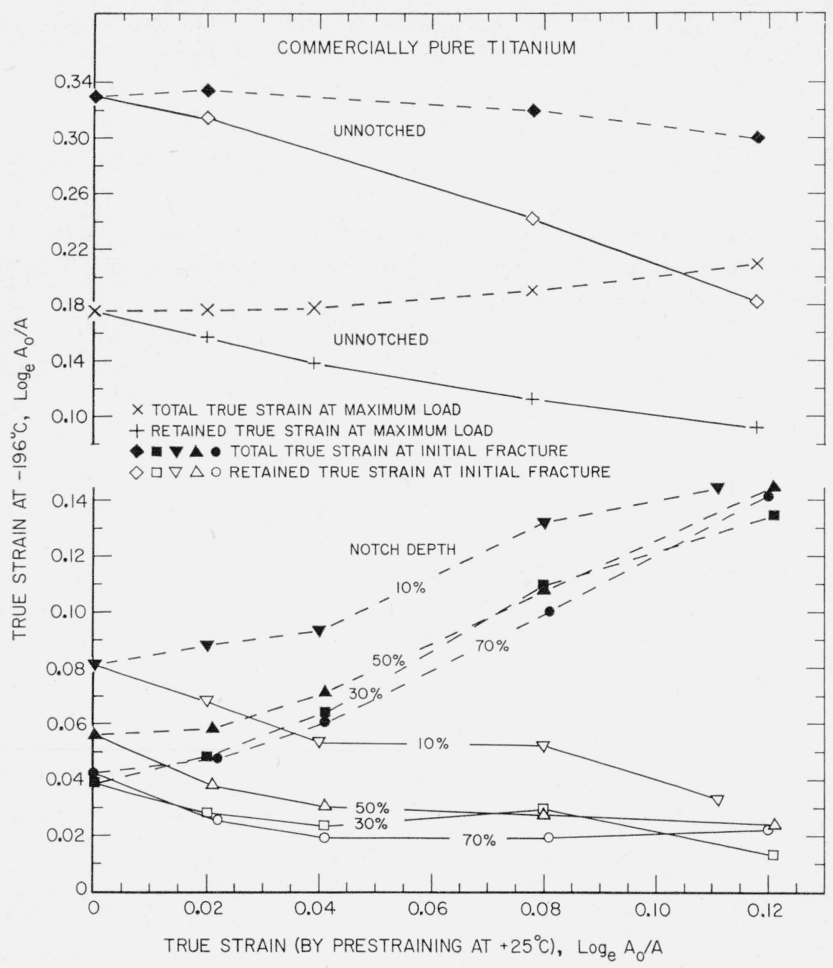

FIgurE 9. Effect of prestraining in tension at $+25^{\circ} \mathrm{C}$ on the ductility at $-196^{\circ} \mathrm{C}$ of unnotched and notched specimens of titanium.

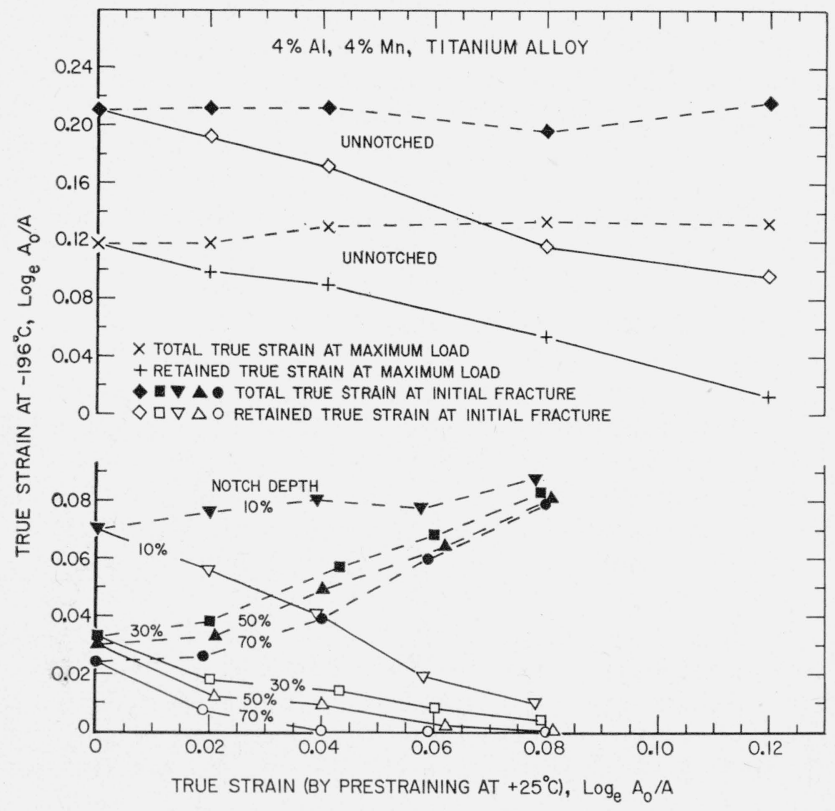

FIGURE 10. Effect of prestraining in tension at $+25^{\circ} \mathrm{C}$ on the ductility at $-196^{\circ} \mathrm{C}$ of unnotched and notched specimens of the alloy.
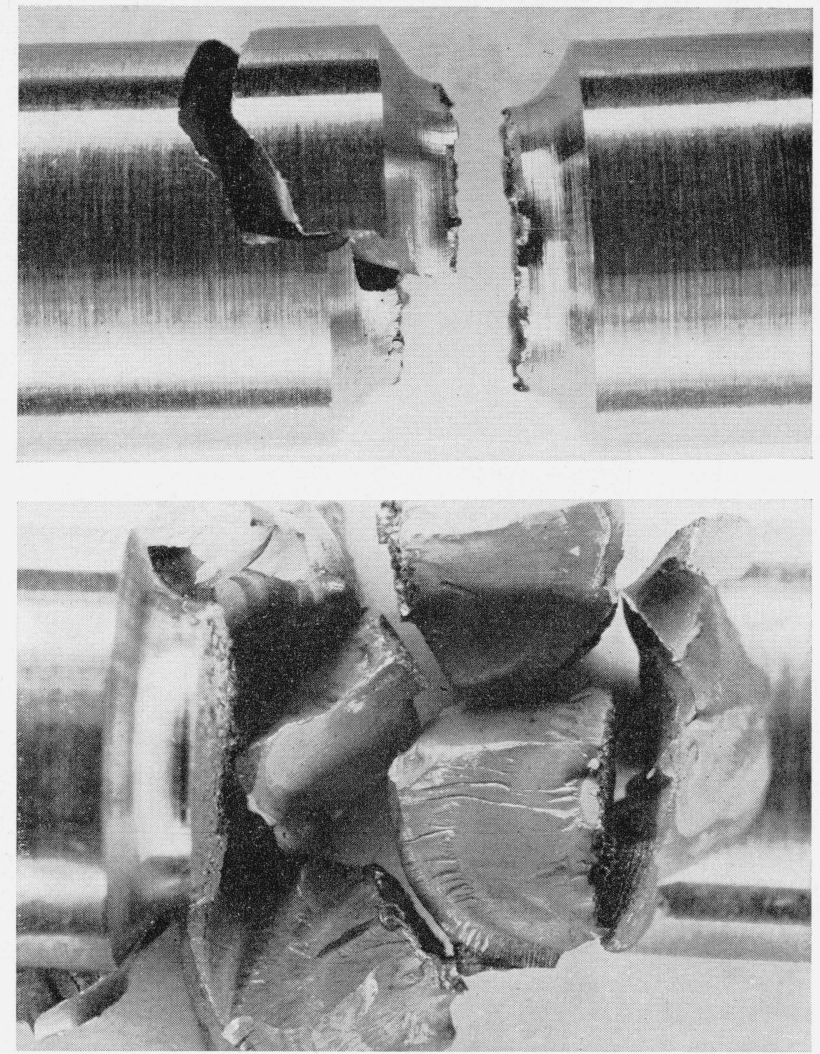

Figure 11. Photographs of notched specimens of 4-percent$A l$, 4-percent-Mn, titanium alloy that were fractured at $-196^{\circ} \mathrm{C}$.

$\times 3 \frac{1}{2}$ Top: Prestrained to a true strain of 0.04 at $+25^{\circ} \mathrm{C}$. Bottom: Prestrained to a true strain of 0.06 at $+25^{\circ} \mathrm{C}$.

the notched specimens at $-196^{\circ} \mathrm{C}$. A major portion of this increase can be attributed directly to the prestrain. It follows, therefore, that the retained true strains at initial fracture of the notched specimens at $-196^{\circ} \mathrm{C}$ decreased to very small values with increase in the prestrain at $+25^{\circ} \mathrm{C}$. Some of the prestrained specimens, particularly the deepnotched alloy, broke in a very brittle manner at $-196^{\circ} \mathrm{C}$. Two examples of these brittle fractures are shown in figure 11.

The results obtained in this series of two-stage tension tests at $+25^{\circ}$ and $-196^{\circ} \mathrm{C}$, respectively, on unnotched and notched specimens indicate that multiaxial stresses and prestrain in tension at $+25^{\circ}$ $\mathrm{C}$ both increase the embrittlement of the annealed titanium and the annealed 4-percent-Al, 4-percent$\mathrm{Mn}$, titanium alloy at $-196^{\circ} \mathrm{C}$.

\subsection{Effect of Prestraining Specimens at $+25^{\circ} \mathrm{C}$ on Their Tensile Properties at $+100^{\circ} \mathrm{C}$}

The results obtained in two-stage tension tests at $+25^{\circ}$ and $+100^{\circ} \mathrm{C}$, respectively, on unnotched and notched specimens of the titanium and titanium alloy are summarized in table 2 . 
TABLE 2. Tensile properties of unnotched and notched ( $60^{\circ}$ notch angle, 0.05 in. root radius) specimens tested in single stage at $+100^{\circ} \mathrm{C}$ and in two stages at $+25^{\circ}$ and $+100^{\circ} \mathrm{C}$, respectively

\begin{tabular}{|c|c|c|c|c|c|c|c|c|c|c|c|c|c|c|c|}
\hline \multirow{3}{*}{$\begin{array}{l}\text { Notch } \\
\text { depth }\end{array}$} & \multirow{3}{*}{$D$ a } & \multirow{3}{*}{$d \mathrm{~b}$} & \multirow{3}{*}{$\begin{array}{c}\text { Stress } \\
\text { con- } \\
\text { cen- } \\
\text { tra- } \\
\text { tion } \\
\text { factor } \\
K_{t}\end{array}$} & \multirow{3}{*}{$\begin{array}{l}\text { Triaxi- } \\
\text { ality, } \\
S_{t} / S_{l}\end{array}$} & \multicolumn{2}{|c|}{$\begin{array}{l}\text { First stage of test, } \\
\qquad+25^{\circ} \mathrm{C}\end{array}$} & \multicolumn{7}{|c|}{ Second stage of test, $+100^{\circ} \mathrm{C}$} & \multirow{3}{*}{$\begin{array}{c}\text { Reduc- } \\
\text { tion of } \\
\text { area }\end{array}$} & \multirow{3}{*}{$\begin{array}{l}\text { Elonga- } \\
\text { tion } \mathrm{f} \\
\text { in } 2 \text { in. }\end{array}$} \\
\hline & & & & & \multirow{2}{*}{$\begin{array}{c}\text { True } \\
\text { strain d } \\
\text { at end } \\
\text { of stage }\end{array}$} & \multirow{2}{*}{$\begin{array}{c}\text { True stress } \\
\text { at end } \\
\text { of stage }\end{array}$} & \multirow{2}{*}{$\begin{array}{l}\text { Tensile e } \\
\text { strength } \\
\text { or notch } \\
\text { strength }\end{array}$} & \multicolumn{2}{|c|}{ True stress } & \multicolumn{2}{|c|}{ Total true strain $\mathrm{d}$} & \multicolumn{2}{|c|}{$\begin{array}{l}\text { Retained true } \\
\text { strain }\end{array}$} & & \\
\hline & & & & & & & & $\begin{array}{l}\text { at maxi- } \\
\text { mum load }\end{array}$ & $\begin{array}{l}\text { at initial } \\
\text { fracture }\end{array}$ & $\begin{array}{l}\text { at maxi- } \\
\text { mum } \\
\text { load }\end{array}$ & $\begin{array}{c}\text { at ini- } \\
\text { tial } \\
\text { fracture }\end{array}$ & $\begin{array}{c}\text { at maxi- } \\
\text { load }\end{array}$ & $\begin{array}{c}\text { at ini- } \\
\text { tial } \\
\text { fracture }\end{array}$ & & \\
\hline
\end{tabular}

Commercially pure titanium

\begin{tabular}{|c|c|c|c|c|c|c|c|c|c|c|c|c|c|c|c|}
\hline $\begin{array}{l}\% \\
0 \mathrm{~g} \\
0 \\
0 \\
0 \\
0\end{array}$ & $\begin{array}{l}\text { in. } \\
-. \\
-\end{array}$ & $\begin{array}{c}\text { in. } \\
0.400 \\
.400 \\
.400 \\
.400 \\
.400\end{array}$ & $\begin{array}{l}1.0 \\
1.0 \\
1.0 \\
1.0 \\
1.0\end{array}$ & $\begin{array}{l}0 \\
0 \\
0 \\
0 \\
0\end{array}$ & $\begin{array}{l}0 \\
.020 \\
.040 \\
.080 \\
.120\end{array}$ & $\begin{array}{r}l b / \text { in. }^{2} \\
0 \\
80,000 \\
89.000 \\
99,000 \\
107,000\end{array}$ & $\begin{array}{c}l b / \text { in }^{2} \\
75,000 \\
75,000 \\
75,000 \\
75,000 \\
75,000\end{array}$ & $\begin{array}{l}l b / \text { in. } .^{2} \\
85,000 \\
87,000 \\
86,000 \\
87,000 \\
88,000\end{array}$ & $\begin{array}{l}l b / \text { in }^{2} \\
118,000 \\
123,000 \\
123,000 \\
125,000 \\
123,000\end{array}$ & $\begin{array}{r}0.130 \\
.153 \\
.135 \\
.138 \\
.164\end{array}$ & $\begin{array}{r}0.785 \\
.807 \\
.799 \\
.813 \\
.805\end{array}$ & $\begin{array}{l}0.130 \\
.133 \\
.095 \\
.058 \\
.044\end{array}$ & $\begin{array}{r}0.785 \\
.787 \\
.759 \\
.733 \\
.685\end{array}$ & $\begin{array}{l}\% \\
57 \\
56 \\
56 \\
56 \\
56\end{array}$ & $\begin{array}{l}\% \\
41 \\
36 \\
36 \\
36 \\
36\end{array}$ \\
\hline $\begin{array}{l}10 \mathrm{~g} \\
10 \\
10 \\
10 \\
10\end{array}$ & $\begin{array}{r}0.370 \\
.370 \\
.370 \\
.370 \\
.370\end{array}$ & $\begin{array}{l}.350 \\
.350 \\
.350 \\
.350 \\
.350\end{array}$ & $\begin{array}{l}1.7 \\
1.7 \\
1.7 \\
1.7 \\
1.7\end{array}$ & $\begin{array}{l}0 \\
.08 \\
.08 \\
.08 \\
.08\end{array}$ & $\begin{array}{l}0 \\
.020 \\
.040 \\
.081 \\
.122\end{array}$ & $\begin{array}{r}0 \\
85,000 \\
95,000 \\
106,000 \\
116,000\end{array}$ & $\begin{array}{l}82,000 \\
81,000 \\
81,000 \\
81,000 \\
81,000\end{array}$ & $\begin{array}{l}94,000 \\
92,000 \\
93,000 \\
93,000 \\
95,000\end{array}$ & $\begin{array}{l}122,000 \\
123,000 \\
123,000 \\
120,000 \\
122,000\end{array}$ & $\begin{array}{l}.134 \\
.131 \\
.144 \\
.141 \\
.159\end{array}$ & $\begin{array}{l}.528 \\
.533 \\
.543 \\
.512 \\
.508\end{array}$ & $\begin{array}{l}.134 \\
.111 \\
.104 \\
.060 \\
.037\end{array}$ & $\begin{array}{l}.528 \\
.513 \\
.503 \\
.431 \\
.386\end{array}$ & $\begin{array}{l}40 \\
40 \\
41 \\
39 \\
39\end{array}$ & $\begin{array}{l}\ldots- \\
\cdots \cdots \\
\cdots \cdots \\
\cdots\end{array}$ \\
\hline $\begin{array}{l}30 \\
30 \\
30 \\
30 \\
30\end{array}$ & $\begin{array}{l}.418 \\
.418 \\
.418 \\
.418 \\
.418\end{array}$ & $\begin{array}{l}.350 \\
.350 \\
.350 \\
.350 \\
.350\end{array}$ & $\begin{array}{l}1.9 \\
1.9 \\
1.9 \\
1.9 \\
1.9\end{array}$ & $\begin{array}{l}.23 \\
.23 \\
.23 \\
.23 \\
.23\end{array}$ & $\begin{array}{l}0 \\
.020 \\
.039 \\
.081 \\
.121\end{array}$ & $\begin{array}{r}0 \\
103,000 \\
112,000 \\
123,000 \\
135,000\end{array}$ & $\begin{array}{l}98,000 \\
96,000 \\
96,000 \\
96.000 \\
95,000\end{array}$ & $\begin{array}{l}116,000 \\
114,000 \\
115,000 \\
116,000 \\
117,000\end{array}$ & $\begin{array}{l}130,000 \\
132,000 \\
129,000 \\
128,000 \\
131,000\end{array}$ & $\begin{array}{l}.173 \\
.174 \\
.181 \\
.191 \\
.208\end{array}$ & $\begin{array}{l}.363 \\
.359 \\
.346 \\
.346 \\
.367\end{array}$ & $\begin{array}{l}.173 \\
.154 \\
.142 \\
.110 \\
.087\end{array}$ & $\begin{array}{l}.363 \\
.339 \\
.307 \\
.265 \\
.246\end{array}$ & $\begin{array}{l}30 \\
32 \\
30 \\
30 \\
30\end{array}$ & $\ldots$ \\
\hline $\begin{array}{l}50 \mathrm{~g} \\
50 \\
50 \\
50 \\
50\end{array}$ & $\begin{array}{l}.495 \\
.495 \\
.495 \\
.495 \\
.495\end{array}$ & $\begin{array}{l}.350 \\
.350 \\
.350 \\
.350 \\
.350\end{array}$ & $\begin{array}{l}2.0 \\
2.0 \\
2.0 \\
2.0 \\
2.0\end{array}$ & $\begin{array}{l}.33 \\
.33 \\
.33 \\
.33 \\
.33\end{array}$ & $\begin{array}{l}0 \\
.021 \\
.041 \\
.082 \\
.123\end{array}$ & $\begin{array}{r}0 \\
120,000 \\
132,000 \\
146,000 \\
155,000\end{array}$ & $\begin{array}{l}108,000 \\
108,000 \\
108,000 \\
110,000 \\
109,000\end{array}$ & $\begin{array}{l}128,000 \\
128,000 \\
128,000 \\
133,000 \\
134,000\end{array}$ & $\begin{array}{l}142,000 \\
143,000 \\
141,000 \\
144,000 \\
143,000\end{array}$ & $\begin{array}{l}.158 \\
.166 \\
.167 \\
.185 \\
.205\end{array}$ & $\begin{array}{l}.343 \\
.330 \\
.327 \\
.329 \\
.305\end{array}$ & $\begin{array}{l}.158 \\
.145 \\
.126 \\
.103 \\
.082\end{array}$ & $\begin{array}{l}.343 \\
.309 \\
.286 \\
.227 \\
.182\end{array}$ & $\begin{array}{l}29 \\
29 \\
28 \\
28 \\
27\end{array}$ & $\begin{array}{c}-\cdots \\
-\cdots \\
-\cdots \\
--.\end{array}$ \\
\hline $\begin{array}{l}70 \mathrm{~g} \\
70 \\
70 \\
70 \\
70\end{array}$ & $\begin{array}{l}.639 \\
.639 \\
.639 \\
.639 \\
.639\end{array}$ & $\begin{array}{l}.350 \\
.350 \\
.350 \\
.350 \\
.350\end{array}$ & $\begin{array}{l}2.1 \\
2.1 \\
2.1 \\
2.1 \\
2.1\end{array}$ & $\begin{array}{l}.39 \\
.39 \\
.39 \\
.39 \\
.39\end{array}$ & $\begin{array}{l}0 \\
.021 \\
.041 \\
.082 \\
.123\end{array}$ & $\begin{array}{r}0 \\
118,000 \\
144,000 \\
166.000 \\
175,000\end{array}$ & $\begin{array}{l}119,000 \\
119,000 \\
118,000 \\
120,000 \\
119,000\end{array}$ & $\begin{array}{l}137,000 \\
137,000 \\
136,000 \\
139,000 \\
143,000\end{array}$ & $\begin{array}{l}154,000 \\
153,000 \\
152.000 \\
153,000 \\
155,000\end{array}$ & $\begin{array}{l}.137 \\
.141 \\
.142 \\
.149 \\
.182\end{array}$ & $\begin{array}{l}.369 \\
.364 \\
.372 \\
.375 \\
.360\end{array}$ & $\begin{array}{l}.137 \\
.120 \\
.101 \\
.067 \\
.059\end{array}$ & $\begin{array}{l}.369 \\
.343 \\
.331 \\
.293 \\
.237\end{array}$ & $\begin{array}{l}31 \\
31 \\
32 \\
31 \\
29\end{array}$ & $\begin{array}{l}-\cdots \\
-\cdots \\
-\cdots \\
-\cdots\end{array}$ \\
\hline $\begin{array}{l}87 \\
87 \\
87 \\
87 \\
87\end{array}$ & $\begin{array}{l}.990 \\
.990 \\
.990 \\
.990 \\
.990\end{array}$ & $\begin{array}{l}.350 \\
.350 \\
.350 \\
.350 \\
.350\end{array}$ & $\begin{array}{l}2.1 \\
2.1 \\
2.1 \\
2.1 \\
2.1\end{array}$ & $\begin{array}{l}.41 \\
.41 \\
.41 \\
.41 \\
.41\end{array}$ & $\begin{array}{l}0 \\
.020 \\
.040 \\
.081 \\
.123\end{array}$ & $\begin{array}{r}0 \\
123,000 \\
147,000 \\
163,000 \\
182,000\end{array}$ & $\begin{array}{l}125,000 \\
122,000 \\
122,000 \\
121,000 \\
123,000\end{array}$ & $\begin{array}{l}143,000 \\
140,000 \\
142,000 \\
141,000 \\
145,000\end{array}$ & $\begin{array}{l}157,000 \\
156,000 \\
155,000 \\
155,000 \\
154,000\end{array}$ & $\begin{array}{l}.135 \\
.142 \\
.146 \\
.150 \\
.167\end{array}$ & $\begin{array}{l}.318 \\
.320 \\
.314 \\
.317 \\
.276\end{array}$ & $\begin{array}{l}.135 \\
.122 \\
.106 \\
.069 \\
.044\end{array}$ & $\begin{array}{l}.318 \\
.300 \\
.274 \\
.236 \\
.153\end{array}$ & $\begin{array}{l}29 \\
28 \\
28 \\
28 \\
25\end{array}$ & $\begin{array}{l}-\cdots \\
-\cdots \\
-\cdots \\
-\cdots\end{array}$ \\
\hline
\end{tabular}

4-percent-Al, 4-percent-Mn, titanium alloy

\begin{tabular}{|c|c|c|c|c|c|c|c|c|c|c|c|c|c|c|c|}
\hline $\begin{array}{l}0 \\
0 \\
0 \\
0 \\
0 \\
0 \\
0 \\
0\end{array}$ & 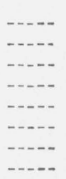 & $\begin{array}{l}0.400 \\
.400 \\
.400 \\
.400 \\
.400 \\
.400 \\
.400 \\
.400\end{array}$ & $\begin{array}{l}1.0 \\
1.0 \\
1.0 \\
1.0 \\
1.0 \\
1.0 \\
1.0 \\
1.0\end{array}$ & $\begin{array}{l}0 \\
.00 \\
.00 \\
.00 \\
.00 \\
.00 \\
.00 \\
.00\end{array}$ & $\begin{array}{l}0 \\
.020 \\
.020 \\
.041 \\
.040 \\
.080 \\
.112 \\
.121\end{array}$ & $\begin{array}{r}0 \\
144,000 \\
145,000 \\
152,000 \\
149,000 \\
160,000 \\
166,000 \\
167,000\end{array}$ & $\begin{array}{l}137,000 \\
137,000 \\
137,000 \\
137,000 \\
137,000 \\
137,000 \\
138,000 \\
139,000\end{array}$ & $\begin{array}{l}155,000 \\
155,000 \\
156,000 \\
158,000 \\
157,000 \\
156,000 \\
156,000 \\
159,000\end{array}$ & $\begin{array}{l}213,000 \\
214,000 \\
216,000 \\
213,000 \\
211,000 \\
211,000 \\
212,000 \\
209,000\end{array}$ & $\begin{array}{l}0.122 \\
.125 \\
.126 \\
.143 \\
.140 \\
.127 \\
.121 \\
.135\end{array}$ & $\begin{array}{r}0.645 \\
.665 \\
.674 \\
.660 \\
.646 \\
.640 \\
.640 \\
.610\end{array}$ & $\begin{array}{l}0.122 \\
.105 \\
.106 \\
.102 \\
.100 \\
.047 \\
.009 \\
.014\end{array}$ & $\begin{array}{r}0.645 \\
.645 \\
.654 \\
.619 \\
.606 \\
.560 \\
.528 \\
.489\end{array}$ & $\begin{array}{l}47 \\
49 \\
49 \\
49 \\
48 \\
50 \\
48 \\
46\end{array}$ & $\begin{array}{l}15 \\
20 \\
20 \\
19 \\
19 \\
20 \\
20 \\
18\end{array}$ \\
\hline $\begin{array}{l}10 \\
10 \\
10 \\
10 \\
10\end{array}$ & $\begin{array}{r}0.370 \\
.370 \\
.370 \\
.370 \\
.370\end{array}$ & $\begin{array}{l}.350 \\
.350 \\
.350 \\
.350 \\
.350\end{array}$ & $\begin{array}{l}1.7 \\
1.7 \\
1.7 \\
1.7 \\
1.7\end{array}$ & $\begin{array}{l}.08 \\
.08 \\
.08 \\
.08 \\
.08\end{array}$ & $\begin{array}{l}0 \\
.020 \\
.040 \\
.061 \\
.080\end{array}$ & $\begin{array}{r}0 \\
160,000 \\
165,000 \\
173,000 \\
177,000\end{array}$ & $\begin{array}{l}153,000 \\
153,000 \\
151,000 \\
151,000 \\
151,000\end{array}$ & $\begin{array}{l}176,000 \\
174,000 \\
175,000 \\
174,000 \\
174,000\end{array}$ & $\begin{array}{l}188,000 \\
186,000 \\
183,000 \\
184,000 \\
184,000\end{array}$ & $\begin{array}{l}.138 \\
.130 \\
.146 \\
.141 \\
.141\end{array}$ & $\begin{array}{l}.224 \\
.205 \\
.200 \\
.204 \\
.215\end{array}$ & $\begin{array}{l}.138 \\
.110 \\
.106 \\
.080 \\
.061\end{array}$ & $\begin{array}{l}.224 \\
.185 \\
.160 \\
.143 \\
.135\end{array}$ & $\begin{array}{l}23 \\
22 \\
22 \\
21 \\
23\end{array}$ & -.. \\
\hline $\begin{array}{l}30 \\
30 \\
30 \\
30 \\
30\end{array}$ & $\begin{array}{l}.418 \\
.418 \\
.418 \\
.418 \\
.418\end{array}$ & $\begin{array}{l}.350 \\
.350 \\
.350 \\
.350 \\
.350\end{array}$ & $\begin{array}{l}1.9 \\
1.9 \\
1.9 \\
1.9 \\
1.9\end{array}$ & $\begin{array}{l}.23 \\
.23 \\
.23 \\
.23 \\
.23\end{array}$ & $\begin{array}{l}0 \\
.020 \\
.040 \\
.061 \\
.082\end{array}$ & $\begin{array}{r}0 \\
175,000 \\
195,000 \\
198,000 \\
205,000\end{array}$ & $\begin{array}{l}175,000 \\
174,000 \\
175,000 \\
173,000 \\
173,000\end{array}$ & $\begin{array}{l}201,000 \\
199.000 \\
197,000 \\
198,000 \\
195,000\end{array}$ & $\begin{array}{l}204,000 \\
201,000 \\
201,000 \\
199,000 \\
199,000\end{array}$ & $\begin{array}{l}.138 \\
.134 \\
.119 \\
.139 \\
.123\end{array}$ & $\begin{array}{l}.156 \\
.147 \\
.144 \\
.147 \\
.136\end{array}$ & $\begin{array}{l}.138 \\
.114 \\
.079 \\
.078 \\
.041\end{array}$ & $\begin{array}{l}.156 \\
.127 \\
.104 \\
.086 \\
.054\end{array}$ & $\begin{array}{l}17 \\
16 \\
16 \\
16 \\
15\end{array}$ & $\begin{array}{l}--.- \\
--- \\
-\cdots \\
---\end{array}$ \\
\hline $\begin{array}{l}50 \\
50 \\
50 \\
50 \\
50 \\
50\end{array}$ & $\begin{array}{l}.495 \\
.495 \\
.495 \\
.495 \\
.495 \\
.495\end{array}$ & $\begin{array}{l}.350 \\
.350 \\
.350 \\
.350 \\
.350 \\
.350\end{array}$ & $\begin{array}{l}2.0 \\
2.0 \\
2.0 \\
2.0 \\
2.0 \\
2.0\end{array}$ & $\begin{array}{l}.33 \\
.33 \\
.33 \\
.33 \\
.33 \\
.33\end{array}$ & $\begin{array}{l}0 \\
.020 \\
.021 \\
.040 \\
.060 \\
.080\end{array}$ & $\begin{array}{r}0 \\
202,000 \\
197,000 \\
216,000 \\
233,000 \\
240,000\end{array}$ & $\begin{array}{l}202,000 \\
199,000 \\
203,000 \\
202,000 \\
201,000 \\
201,000\end{array}$ & $\begin{array}{l}227,000 \\
223,000 \\
227,000 \\
227,000 \\
226,000 \\
220,000\end{array}$ & $\begin{array}{l}232,000 \\
229,000 \\
235,000 \\
234,000 \\
230,000 \\
230,000\end{array}$ & $\begin{array}{l}.118 \\
.116 \\
.113 \\
.116 \\
.119 \\
.089\end{array}$ & $\begin{array}{l}.147 \\
.151 \\
.157 \\
.156 \\
.143 \\
.142\end{array}$ & $\begin{array}{l}.118 \\
.096 \\
.092 \\
.076 \\
.059 \\
.009\end{array}$ & $\begin{array}{l}.147 \\
.131 \\
.136 \\
.116 \\
.083 \\
.062\end{array}$ & $\begin{array}{l}17 \\
17 \\
16 \\
16 \\
16 \\
16\end{array}$ & $\begin{array}{l}--. \\
-\cdots \\
-\cdots \\
-\cdots \\
-\cdots \\
-\cdots\end{array}$ \\
\hline $\begin{array}{l}70 \\
70 \\
70 \\
70 \\
70\end{array}$ & $\begin{array}{r}.639 \\
.639 \\
.639 \\
.639 \\
.639\end{array}$ & $\begin{array}{l}.350 \\
.350 \\
.350 \\
.350 \\
.350\end{array}$ & $\begin{array}{l}2.1 \\
2.1 \\
2.1 \\
2.1 \\
2.1\end{array}$ & $\begin{array}{l}.39 \\
.39 \\
.39 \\
.39 \\
.39\end{array}$ & $\begin{array}{l}0 \\
.020 \\
.040 \\
.060 \\
.081\end{array}$ & $\begin{array}{r}0 \\
205,000 \\
238,000 \\
257,000 \\
265,000\end{array}$ & $\begin{array}{l}223,000 \\
222,000 \\
223,000 \\
223,000 \\
223,000\end{array}$ & $\begin{array}{l}247,000 \\
250,000 \\
250,000 \\
248,000 \\
246,000\end{array}$ & $\begin{array}{l}249,000 \\
255,000 \\
252,000 \\
251,000 \\
252,000\end{array}$ & $\begin{array}{l}.104 \\
.118 \\
.115 \\
.105 \\
.100\end{array}$ & $\begin{array}{l}.114 \\
.143 \\
.128 \\
.126 \\
.125\end{array}$ & $\begin{array}{l}.104 \\
.098 \\
.075 \\
.045 \\
.019\end{array}$ & $\begin{array}{l}.114 \\
.123 \\
.088 \\
.066 \\
.044\end{array}$ & $\begin{array}{l}16 \\
17 \\
15 \\
14 \\
18\end{array}$ & $\begin{array}{l}\cdots-. \\
\cdots-. \\
\cdots-. \\
-\cdots\end{array}$ \\
\hline 87 & .990 & .350 & 2.1 & .41 & 0 & 0 & 226,000 & 252,000 & 252,000 & .100 & .110 & .100 & .110 & 14 & $\ldots$ \\
\hline
\end{tabular}

See footnotes to table 1 . 


\section{a. True Stress Versus True Strain Curves}

The true stress-true strain curves for the unnotched specimens are shown in figures 12 and 13 and those for the notched specimens with notch depths of 10 or 50 percent are shown in figures 14 to 17. True stress-true strain curves were also obtained for the two-stage tests on specimens with notch depths of 30 and 70 percent for both metals and also on titanium specimens with a notch depth of 87 percent; these curves are not shown. The portion of the true stress-true strain curves for the second-stage tests at $+100^{\circ} \mathrm{C}$ of the unnotched and notched specimens of both metals approximately

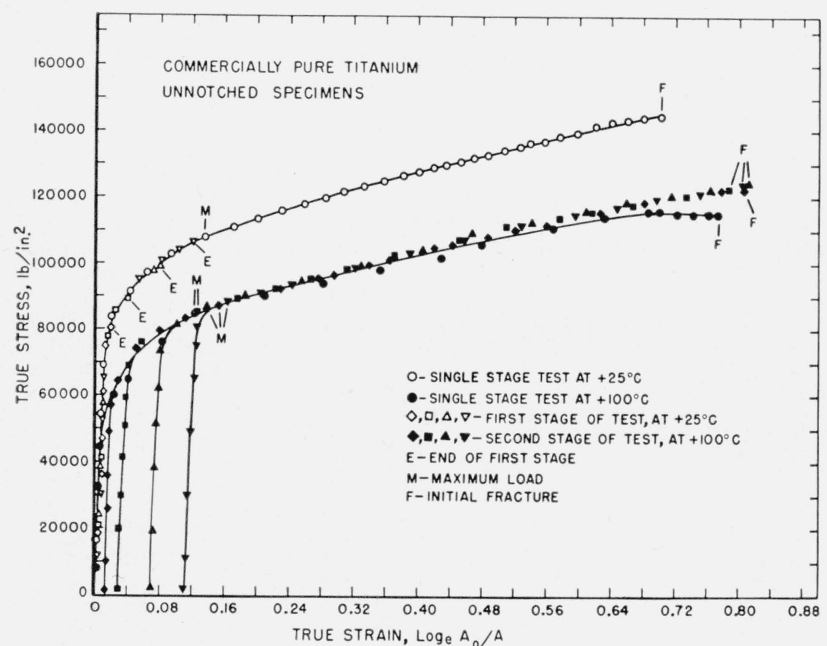

FIGURE 12. True stress-true strain relations obtained in singleand two-stage tension tests at $+25^{\circ}$ and $+100^{\circ} \mathrm{C}$ on unnotched specimens of the titanium.

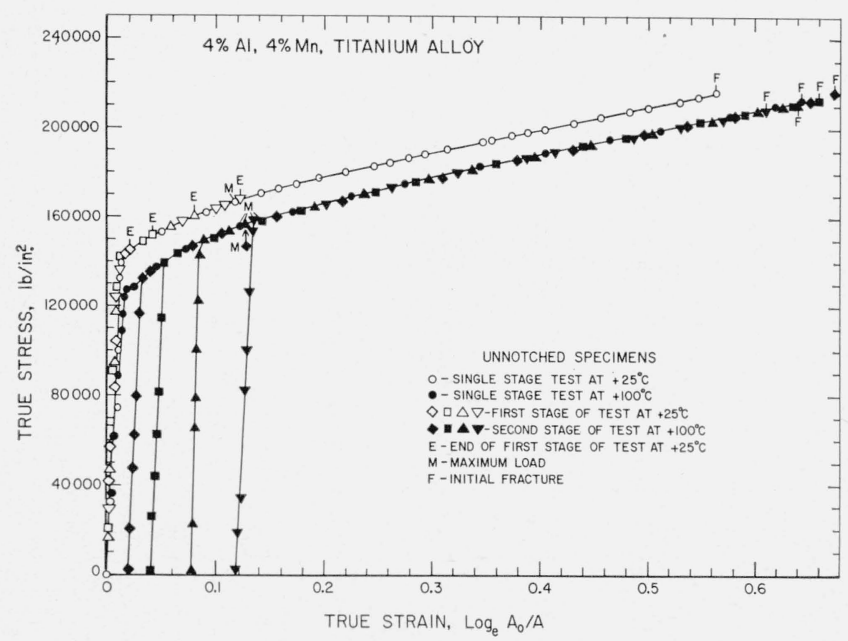

FIGURE 13. True stress-true strain relations obtained in singleand two-stage tension tests at $+25^{\circ}$ and $+100^{\circ} \mathrm{C}$ on unnotched specimens of the alloy. coincide with the corresponding portion of the curves representing single-stage tests at $+100^{\circ}$ C. The total work hardening during the prestraining at $+25^{\circ} \mathrm{C}$ of each of the specimens was approximately equal to the total work hardening of corresponding specimens extended to the same strains at $+100^{\circ} \mathrm{C}$. Thus, the combined effect of the greater rate of strain hardening and the smaller rate of strain aging at $+25^{\circ} \mathrm{C}$ was apparently equal to that of the smaller rate of strain hardening and the greater rate of strain aging at $+100^{\circ} \mathrm{C}$.

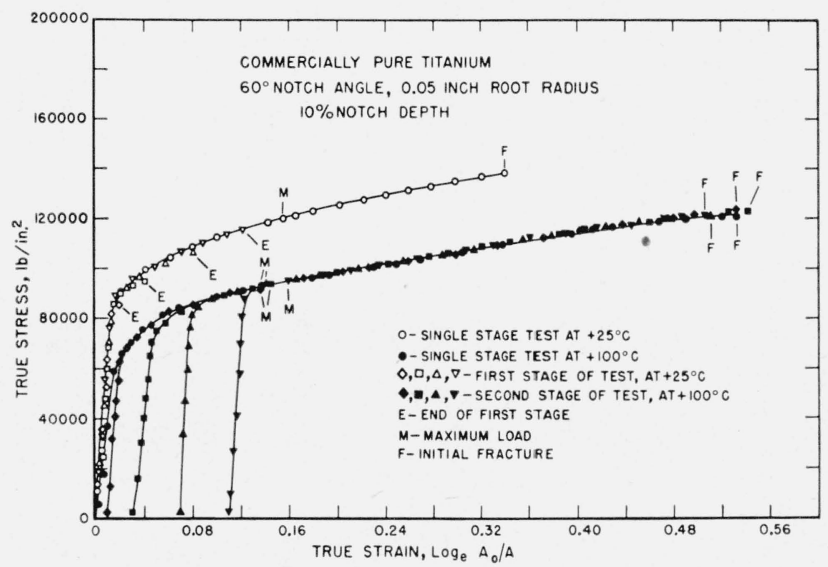

FIGURE 14. True stress-true strain relations obtained in singleand two-stage tension tests at $+25^{\circ}$ and $+100^{\circ} \mathrm{C}$ on notched specimens (10\% notch depth) of the titanium.

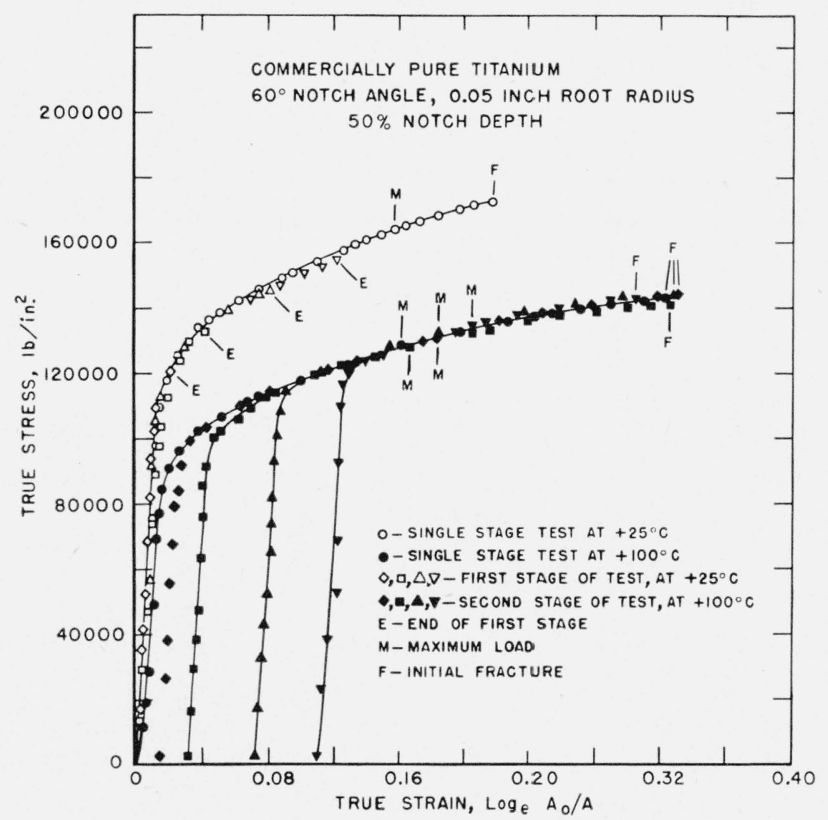

FIGURE 15. True stress-true strain relations obtained in singleand two-stage tension tests at $+25^{\circ}$ and $+100^{\circ} C$ on notched specimens (50\% notch depth) of the titanium. 


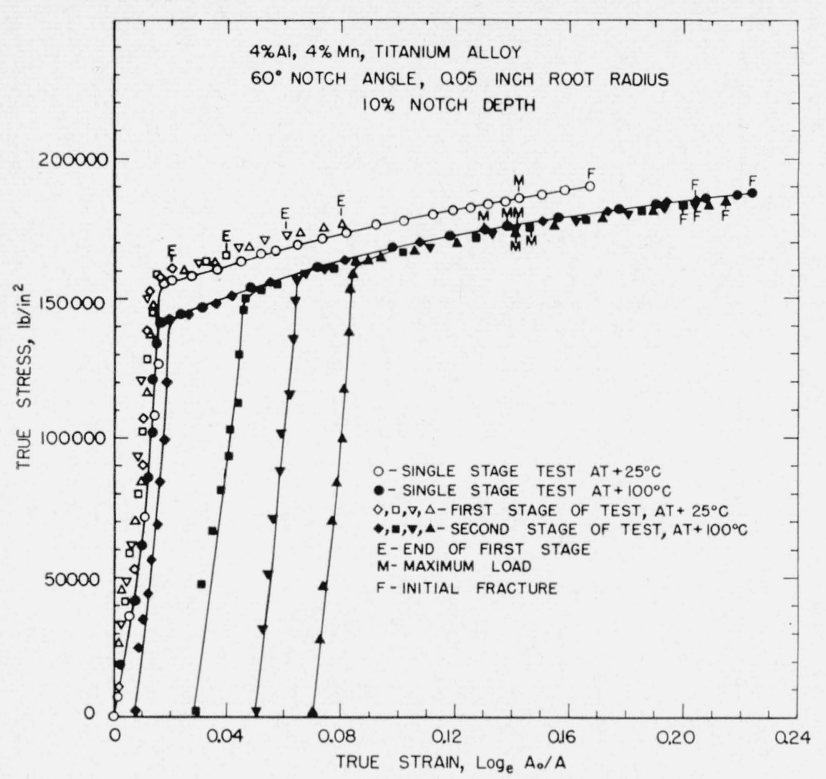

FiguRE 16. True stress-true strain relations obtained in singleand two-stage tension tests at $+25^{\circ}$ and $+100^{\circ} \mathrm{C}$ on notched specimens $(10 \%$ notch depth) of the alloy.

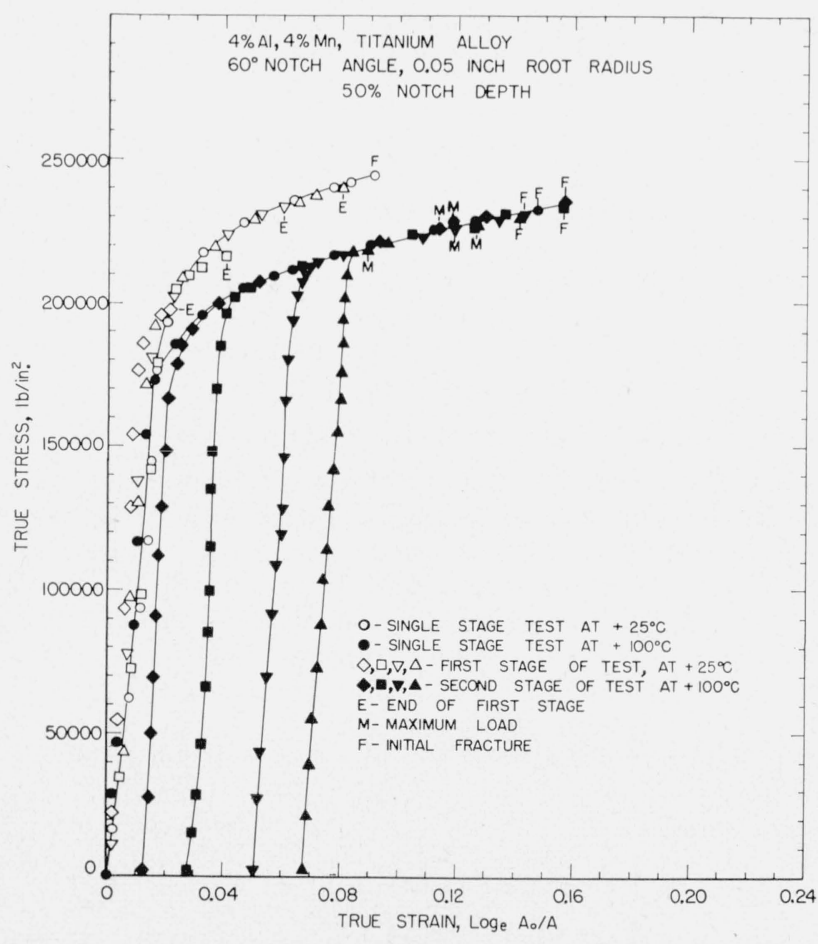

FIgURE 17. True stress-true strain relations obtained in singleand two-stage tension tests at $+25^{\circ}$ and $+100^{\circ} \mathrm{C}$ on notched specimens (50\% notch depth) of the alloy.

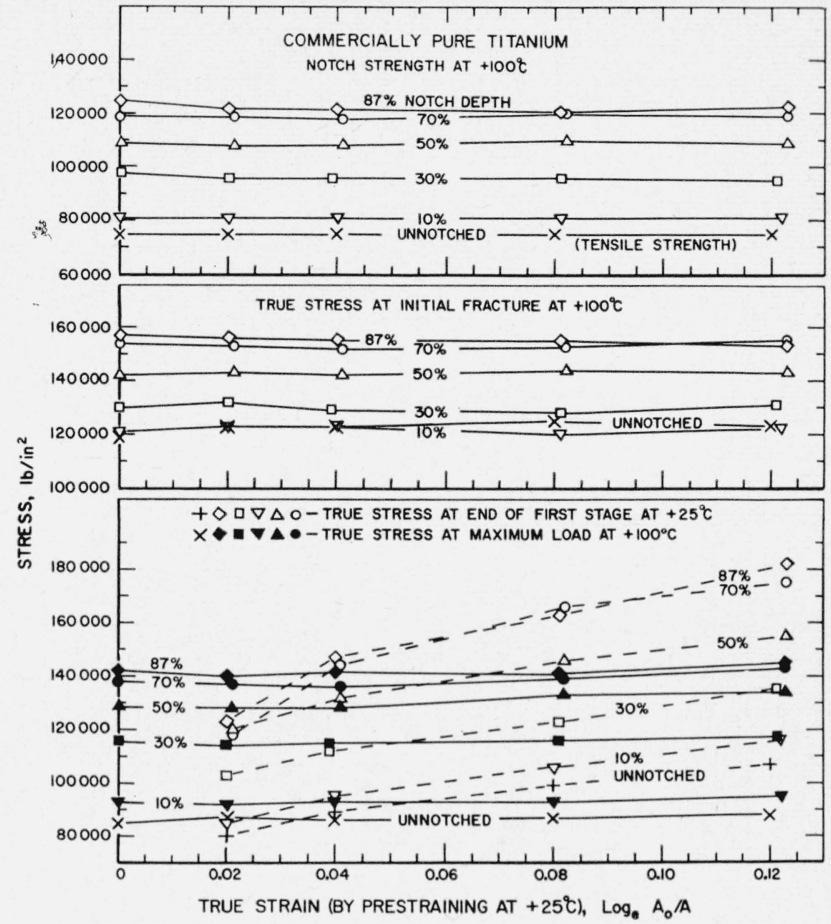

Figure 18. Effect of prestraining in tension at $+25^{\circ} \mathrm{C}$ on the strength at $+100^{\circ} \dot{C}$ of unnotched and notched specimens of the titanium.

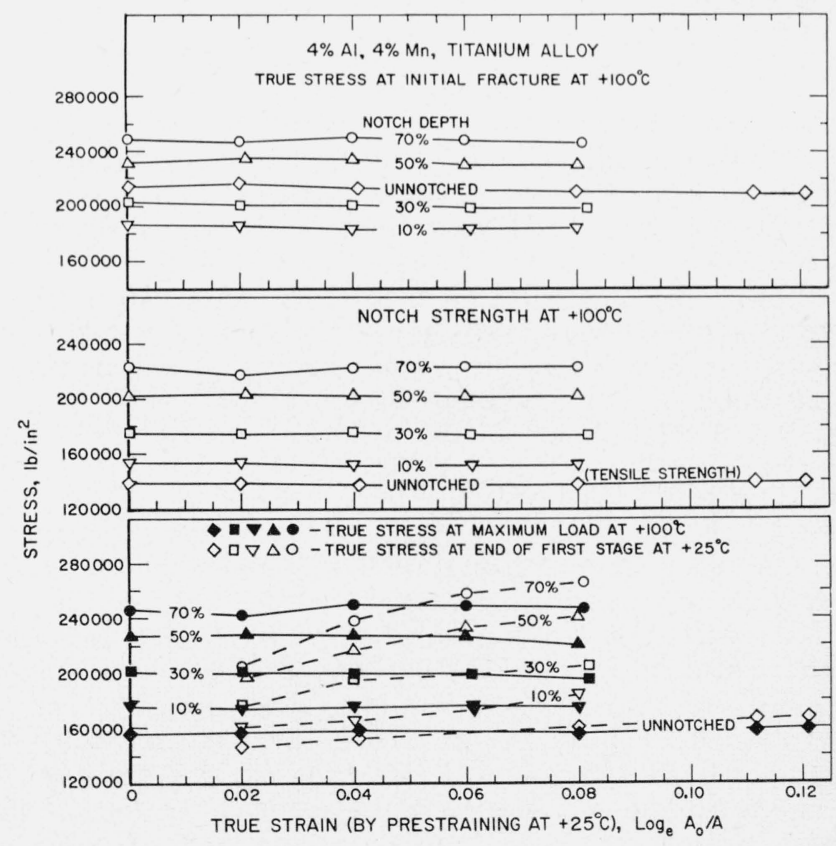

Figure 19. "Effect of prestraining in tension at $+25^{\circ} \mathrm{C}$ on the strength at $+100^{\circ} \mathrm{C}$ of unnotched and notched specimens of the alloy. 


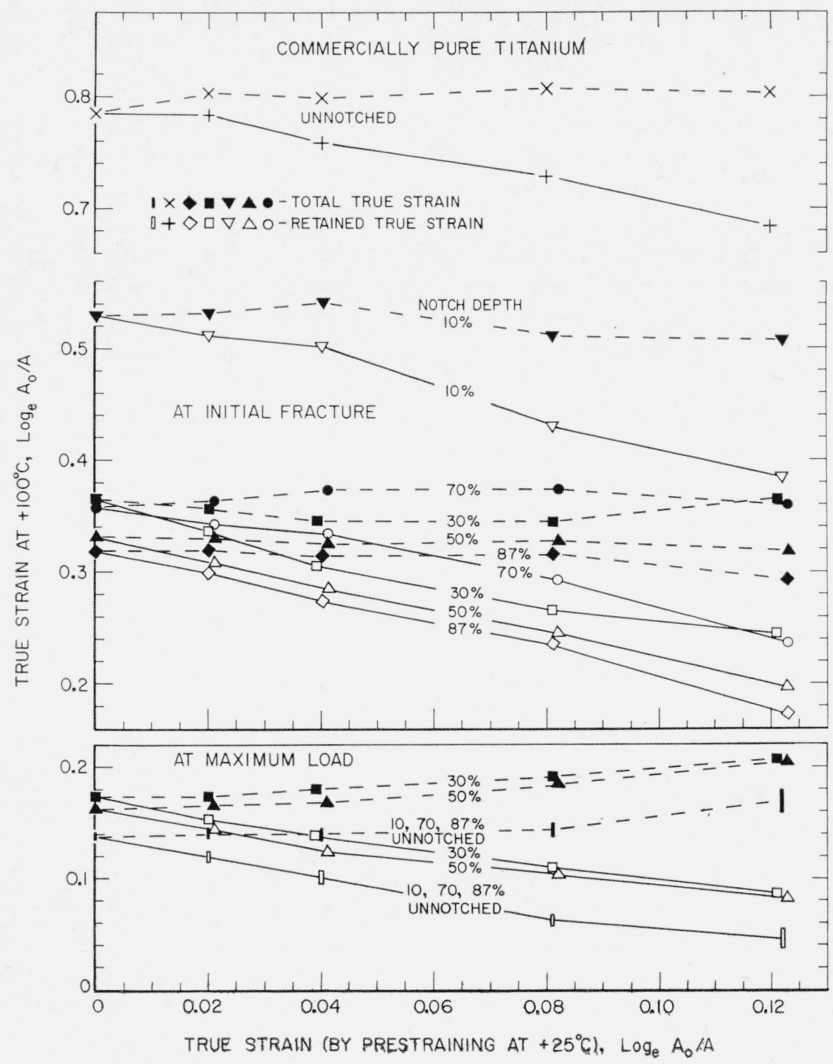

Figure 20. Effect of prestraining in tension at $+25^{\circ} \mathrm{C}$ on the ductility at $+100^{\circ} C$ of unnotched and notched specimens of the titanium.

\section{b. Strength}

The relations observed at $+100^{\circ} \mathrm{C}$ between the tensile or notch strength, true stress at maximum load or true stress at initial fracture, and the prestrain at $+25^{\circ} \mathrm{C}$ of specimens of the titanium and the alloy are shown in figures 18 and 19 . These strength indices increased with the increase in triaxial stresses that accompany the increase in notch depth. However, they were independent of the prestraining of the specimens at $+25^{\circ} \mathrm{C}$.

\section{c. Ductility}

The relations between the ductility at $+100^{\circ} \mathrm{C}$ and the prestrain at $+25^{\circ} \mathrm{C}$ of unnotched and notched specimens are shown in figures 20 and 21 . A slight increase in the total true strain at maximum load with increase in the prestrain was observed for the titanium specimens (fig. 20). However, the increase was much smaller than the prestrain and hence the retained true strain at maximum load generally decreased with increase in the prestrain. The total true strain at initial fracture at $+100^{\circ} \mathrm{C}$ of the unnotched and notched specimens of both metals (figs. 20 and 21) and the total true strain at maximum load at $+100^{\circ} \mathrm{C}$ of the alloy specimens (fig. 21) were approximately independent of the prestrain. Some scatter was obtained in these data, but no general trend is shown of either an increase or decrease in these total true strains with increase in

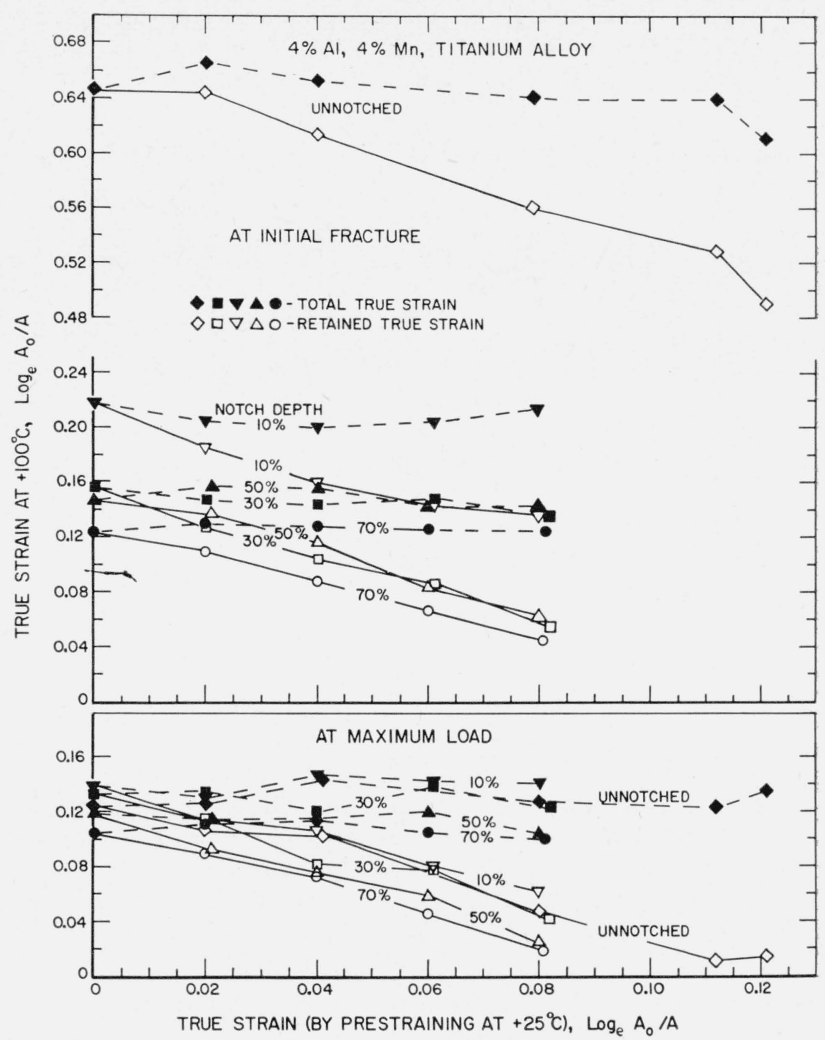

FIGURE 21. Effect of prestraining in tension at $+25^{\circ} \mathrm{C}$ on the ductility at $+100^{\circ} \mathrm{C}$ of unnotched and notched specimens of the alloy.

the prestrain. Thus, the retained true strains at initial fracture at $+100^{\circ} \mathrm{C}$ of both metals and the retained true strains at maximum load at $+100^{\circ} \mathrm{C}$ of the alloy were decreased by the prestraining by amounts approximately equal to the prestrain.

\subsection{Effect of Prestraining Specimens at $-196^{\circ} \mathrm{C}$ on Their Tensile Properties at $+25^{\circ} \mathrm{C}$}

The results obtained in two-stage tension tests at $-196^{\circ}$ and $+25^{\circ} \mathrm{C}$, respectively, on unnotched and notched specimens of the initially annealed titanium and on unnotched specimens of the initially annealed alloy are summarized in table 3 . The ductility of notched specimens of the titanium at $-196^{\circ} \mathrm{C}$ was relatively low and the two-stage tests on these specimens were restricted to small prestrains (true strains of 0.02 and 0.03 ) at $-196^{\circ} \mathrm{C}$. The ductility of notched specimens of the alloy at $-196^{\circ} \mathrm{C}$ was so limited that it was not feasible to conduct the twostage tests.

\section{a. True Stress Versus True Strain Curves}

The true stress-true strain curves obtained on the unnotched specimens of the titanium and the alloy are presented in figures 22 and 23, respectively, and those for the notched specimens (50 percent depth) of titanium in figure 24. The curves for the second stage of these tests at $+25^{\circ} \mathrm{C}$ nearly coincide with the corresponding portion of the curves for single- 
TABLE 3. Tensile properties of unnotched and notched $\left(60^{\circ}\right.$ notch angle, 0.05 in. root radius) specimens tested in single stage at $+25^{\circ} \mathrm{C}$ and in two stages at $-196^{\circ}$ and $+25^{\circ} \mathrm{C}$, respectively

\begin{tabular}{|c|c|c|c|c|c|c|c|c|c|c|c|c|c|c|c|}
\hline \multirow{3}{*}{$\begin{array}{l}\text { Notch } \\
\text { depth }\end{array}$} & \multirow{3}{*}{$D$ a } & \multirow{3}{*}{$d \mathrm{~b}$} & \multirow{3}{*}{$\begin{array}{c}\text { Stress } \\
\text { con- } \\
\text { cen- } \\
\text { tra- } \\
\text { tion } \\
\text { factor, } \\
\mathrm{K}_{t}\end{array}$} & \multirow{3}{*}{$\begin{array}{l}\text { Triaxi- } \\
\text { ality, } \\
S_{t} / S_{1}\end{array}$} & \multicolumn{2}{|c|}{$\begin{array}{c}\text { First stage of test, } \\
-196^{\circ} \mathrm{C}\end{array}$} & \multicolumn{7}{|c|}{ Second stage of test, $+25^{\circ} \mathrm{C}$} & \multirow{3}{*}{$\begin{array}{l}\text { Reduc- } \\
\text { tion of } \\
\text { area }\end{array}$} & \multirow{3}{*}{$\begin{array}{l}\text { Elonga- } \\
\text { tion } \mathrm{f} \\
\text { in } 2 \text { in. }\end{array}$} \\
\hline & & & & & \multirow{2}{*}{$\begin{array}{l}\text { True } \\
\text { strain d } \\
\text { at end } \\
\text { of stage }\end{array}$} & \multirow{2}{*}{$\begin{array}{c}\text { True stress } \\
\text { at end } \\
\text { of stage }\end{array}$} & \multirow{2}{*}{$\begin{array}{l}\text { Tensile e } \\
\text { strength } \\
\text { or notch } \\
\text { strength }\end{array}$} & \multicolumn{2}{|c|}{ True stress } & \multicolumn{2}{|c|}{ Total true strain ${ }^{\mathrm{d}}$} & \multicolumn{2}{|c|}{$\begin{array}{l}\text { Retained true } \\
\text { strain }\end{array}$} & & \\
\hline & & & & & & & & $\begin{array}{l}\text { at maxi- } \\
\text { mum load }\end{array}$ & $\begin{array}{l}\text { at initial } \\
\text { fracture }\end{array}$ & $\begin{array}{l}\text { at maxi- } \\
\text { mum } \\
\text { load }\end{array}$ & $\begin{array}{c}\text { at ini- } \\
\text { tial } \\
\text { fracture }\end{array}$ & $\begin{array}{l}\text { at maxi- } \\
\text { mum } \\
\text { load }\end{array}$ & $\begin{array}{l}\text { at ini- } \\
\text { tial } \\
\text { fracture }\end{array}$ & & \\
\hline \multicolumn{16}{|c|}{ Commercially pure titanium } \\
\hline $\begin{array}{l}\% \\
0 \mathrm{~g} \\
0 \\
0 \\
0 \\
0\end{array}$ & \begin{tabular}{l} 
in. \\
\hdashline- \\
.-
\end{tabular} & $\begin{array}{l}\text { in. } \\
0.400 \\
.400 \\
.400 \\
.400 \\
.400\end{array}$ & $\begin{array}{l}1.0 \\
1.0 \\
1.0 \\
1.0 \\
1.0\end{array}$ & $\begin{array}{l}0 \\
0 \\
0 \\
0 \\
0\end{array}$ & $\begin{array}{l}0 \\
.020 \\
.041 \\
.080 \\
.122\end{array}$ & $\begin{array}{r}l b / \text { in }^{2}{ }^{2} \\
164,000 \\
169,000 \\
179,000 \\
189,000\end{array}$ & $\begin{array}{c}l b / \text { in }^{2} \\
94,000 \\
95,000 \\
94,000 \\
93,000 \\
94,000\end{array}$ & $\begin{array}{l}l b / \text { in }^{2} \\
107,000 \\
108,000 \\
110,000 \\
105,000 \\
107,000\end{array}$ & $\begin{array}{l}l b / \text { in }^{2} \\
145,000 \\
143,000 \\
142,000 \\
134,000 \\
132,000\end{array}$ & $\begin{array}{l}0.130 \\
.122 \\
.152 \\
.127 \\
.135\end{array}$ & $\begin{array}{r}0.706 \\
.659 \\
.635 \\
.577 \\
.536\end{array}$ & $\begin{array}{r}0.130 \\
.102 \\
.111 \\
.047 \\
.013\end{array}$ & $\begin{array}{r}0.706 \\
.639 \\
.594 \\
.497 \\
.414\end{array}$ & $\begin{array}{l}\% \\
52 \\
50 \\
46 \\
45 \\
42\end{array}$ & $\begin{array}{l}\% \\
30 \\
27 \\
23 \\
24 \\
24\end{array}$ \\
\hline $10 \mathrm{~g}$ & 0.370 & .350 & 1.7 & .08 & 0 & 0 & 104,000 & 122,000 & 141,000 & .160 & .360 & .160 & .360 & 32 & -..- \\
\hline $30 \mathrm{~g}$ & .418 & .350 & 1.9 & .23 & 0 & 0 & 123,000 & 146,000 & 155,000 & .175 & .248 & .175 & .248 & 23 & $-\cdots$ \\
\hline $\begin{array}{l}50 \mathrm{~g} \\
50 \\
50\end{array}$ & $\begin{array}{l}.495 \\
.495 \\
.495\end{array}$ & $\begin{array}{l}.350 \\
.350 \\
.350\end{array}$ & $\begin{array}{l}2.0 \\
2.0 \\
2.0\end{array}$ & $\begin{array}{l}.33 \\
.33 \\
.33\end{array}$ & $\begin{array}{l}0 \\
.020 \\
.031\end{array}$ & $\begin{array}{r}0 \\
230,000 \\
245,000\end{array}$ & $\begin{array}{l}141,000 \\
142,000 \\
138,000\end{array}$ & $\begin{array}{l}164,000 \\
165,000 \\
\text { (h) }\end{array}$ & $\begin{array}{l}174,000 \\
168,000 \\
156,000\end{array}$ & $\begin{array}{r}.148 \\
.150 \\
. .-\end{array}$ & $\begin{array}{l}.223 \\
.170 \\
.122\end{array}$ & $\begin{array}{r}.148 \\
.130 \\
. .-\end{array}$ & $\begin{array}{l}.223 \\
.150 \\
.091\end{array}$ & $\begin{array}{l}22 \\
14 \\
12\end{array}$ & -..- \\
\hline $70 \mathrm{~g}$ & .639 & .350 & 2.1 & .39 & 0 & 0 & 159,000 & 180,000 & 193,000 & .126 & .231 & .126 & .231 & 23 & -..- \\
\hline $87 \mathrm{~g}$ & .990 & .350 & 2.1 & .41 & 0 & 0 & 161,000 & 183,000 & 194,000 & .134 & .207 & .134 & .207 & 20 & -..- \\
\hline \multicolumn{16}{|c|}{ 4-percent-Al, 4-percent-Mn, titanium alloy } \\
\hline $\begin{array}{l}0 \mathrm{~g} \\
0 \\
0 \\
0 \\
0\end{array}$ & $\begin{array}{l} \\
\ldots \ldots \\
\ldots \ldots \\
\ldots \ldots \\
\ldots \ldots\end{array}$ & $\begin{array}{r}0.400 \\
.400 \\
.400 \\
.400 \\
.400\end{array}$ & $\begin{array}{l}1.0 \\
1.0 \\
1.0 \\
1.0 \\
1.0\end{array}$ & $\begin{array}{l}0 \\
0 \\
0 \\
0 \\
0\end{array}$ & $\begin{array}{l}0 \\
.020 \\
.041 \\
.081 \\
.122\end{array}$ & $\begin{array}{r}0 \\
247,000 \\
253,000 \\
264,000 \\
275,000\end{array}$ & $\begin{array}{l}149,000 \\
150,000 \\
150,000 \\
151,000 \\
151,000\end{array}$ & $\begin{array}{l}168,000 \\
167,000 \\
168,000 \\
168,000 \\
172,000\end{array}$ & $\begin{array}{l}216,000 \\
215,000 \\
219,000 \\
218,000 \\
214,000\end{array}$ & $\begin{array}{r}0.116 \\
.105 \\
.112 \\
.109 \\
.132\end{array}$ & $\begin{array}{r}0.553 \\
.566 \\
.579 \\
.576 \\
.560\end{array}$ & $\begin{array}{r}0.116 \\
.085 \\
.071 \\
.028 \\
.010\end{array}$ & $\begin{array}{r}0.553 \\
.546 \\
.538 \\
.495 \\
.438\end{array}$ & $\begin{array}{l}44 \\
45 \\
45 \\
45 \\
44\end{array}$ & $\begin{array}{l}14 \\
17 \\
17 \\
13 \\
19\end{array}$ \\
\hline 10 & 0.370 & .350 & 1. 7 & .08 & 0 & 0 & 161,000 & 186,000 & 190,000 & .142 & .167 & .142 & .167 & 17 & --- \\
\hline 30 & .418 & .350 & 1.9 & .23 & 0 & 0 & 191,000 & $(\mathrm{~h})$ & 212,000 & -.... & .101 & $\ldots$ & .101 & 12 & $\cdots$ \\
\hline $50 \mathrm{~g}$ & .495 & .350 & 2.0 & .33 & 0 & 0 & 223,000 & $(\mathrm{~h})$ & 248,000 & -.... & .106 & -... & .106 & 13 & -... \\
\hline 70 & .639 & .350 & 2.1 & .39 & 0 & 0 & 248,000 & (h) & 272,000 & -... & .101 & $\ldots$ & .101 & 12 & -..-. \\
\hline 87 & .990 & .350 & 2.1 & .41 & 0 & 0 & 252,000 & (h) & 270,000 & -... & .068 & $\ldots$ & .068 & -..- & -... \\
\hline
\end{tabular}

See footnotes to table 1.

stage tests at $+25^{\circ} \mathrm{C}$. Thus, the stresses necessary for continued deformation in tension at $+25^{\circ} \mathrm{C}$ were apparently independent of the temperature $\left(-196^{\circ} \mathrm{C}\right.$ or $+25^{\circ} \mathrm{C}$ ) of the prior strain, even though the deformation mechanisms may vary at these two temperatures. The coincidence of the curves also indicates an approximate equivalence of the total work hardening of these specimens during extension in tension to the same selected strains at $-196^{\circ} \mathrm{C}$ or $+25^{\circ} \mathrm{C}$. This conforms to the evidence presented and discussed previously in the series of two-stage tests at $+25^{\circ}$ and $-196^{\circ} \mathrm{C}$.

\section{b. Strength}

Strength indices, such as tensile strength, true stresses at maximum load and at initial fracture, of the unnotched specimens at $+25^{\circ} \mathrm{C}$ of the titanium (fig. 25) and the alloy (fig. 26) were approximately independent of the prestrain at $-196^{\circ} \mathrm{C}$. A similar trend is shown in the limited data on notch strength and true stress at maximum load of the notched specimens of titanium (fig. 25). However, a slight decrease was observed in the true stress at initial fracture at $+25^{\circ} \mathrm{C}$ with increase in the prestrain at $-196^{\circ} \mathrm{C}$ of the notched specimens. This decrease

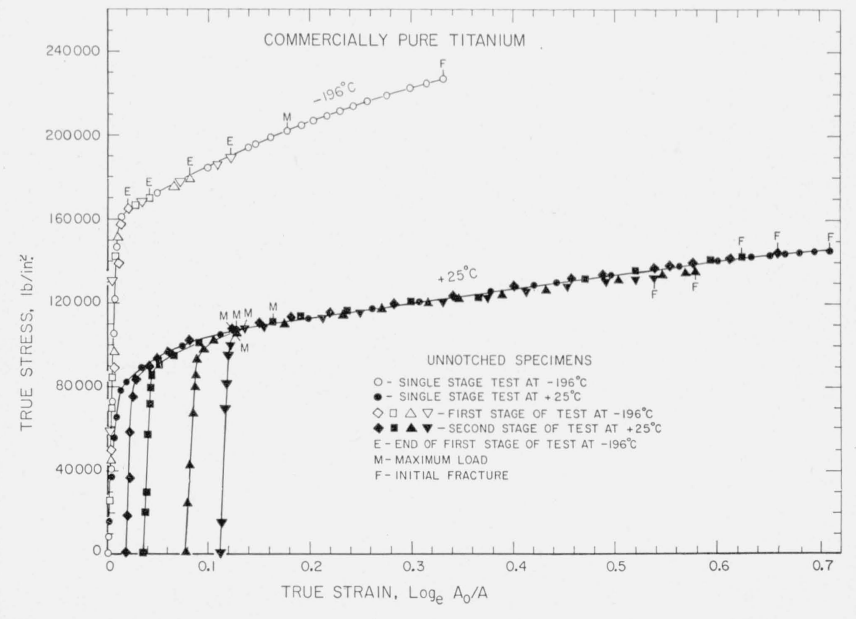

Figure 22. True stress-true strain relations obtained in singleand two-stage tension tests at $-196^{\circ}$ and $+25^{\circ} \mathrm{C}$ on unnotched specimens of the titanium.

can be attributed directly to the reduction in the ductility of these specimens at $+25^{\circ} \mathrm{C}$ by the prestraining at $-196^{\circ} \mathrm{C}$, as no evidence is shown in figure 24 of any decrease in the resistance to deformation of the notchedispecimens at $+25^{\circ} \mathrm{C}$. 


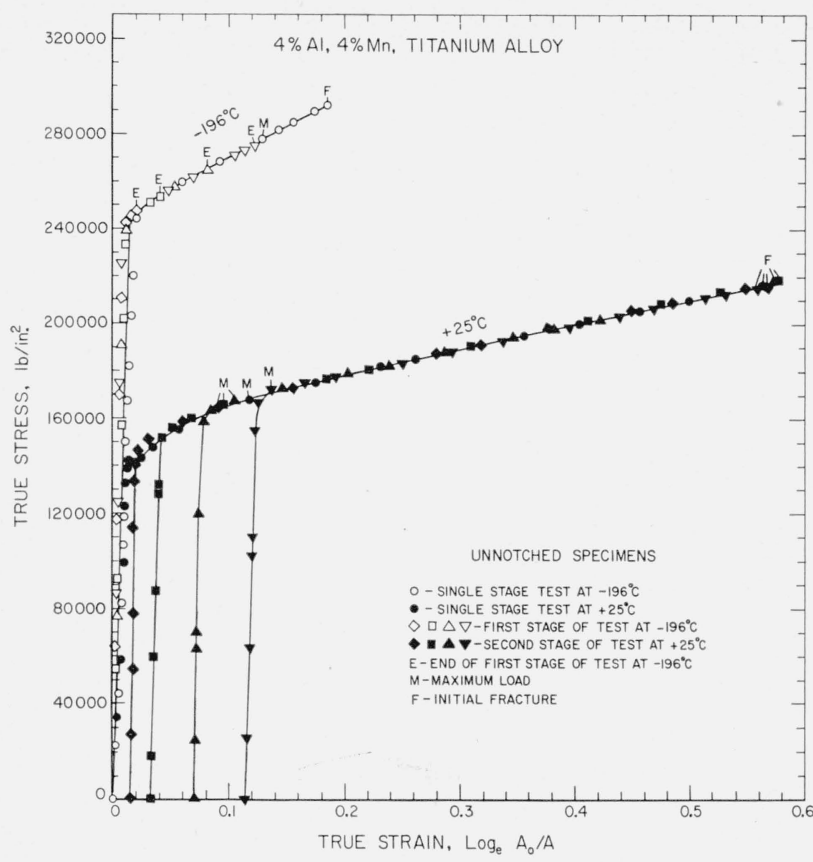

FIGURE 23. True stress-true strain relations obtained in singleand two-stage tension tests at $-196^{\circ}$ and $+25^{\circ} \mathrm{C}$ on unnotched specimens of the alloy.

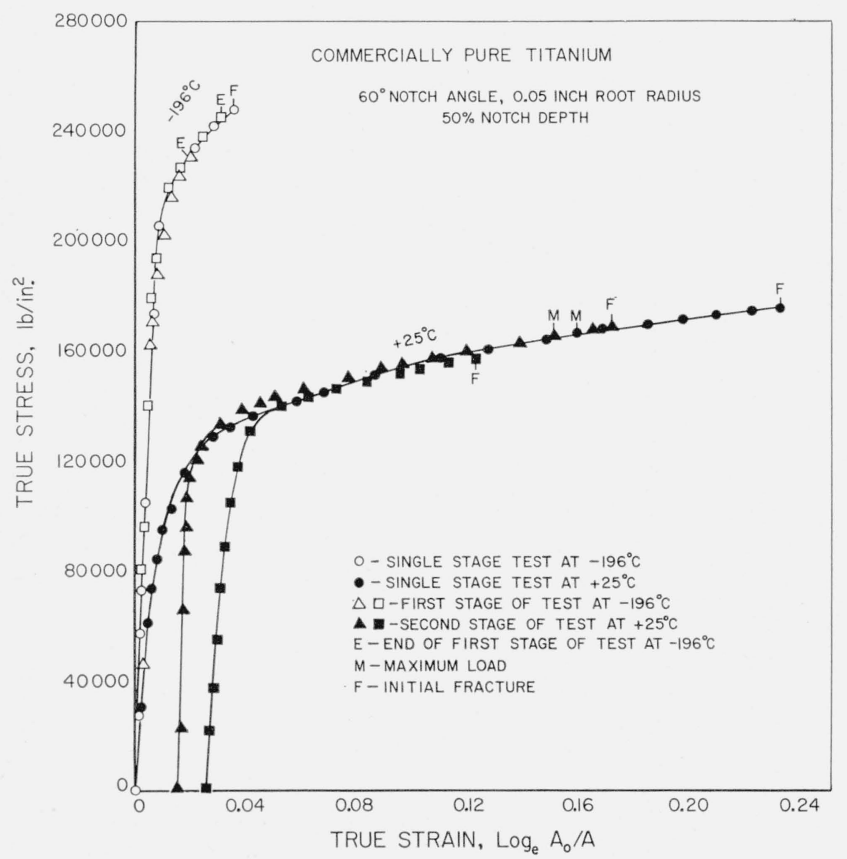

FIGURE 24. True stress-true strain relations obtained in singleand two-stage tension tests at $-196^{\circ}$ and $+25^{\circ} \mathrm{C}$ on notched specimens of the titanium.

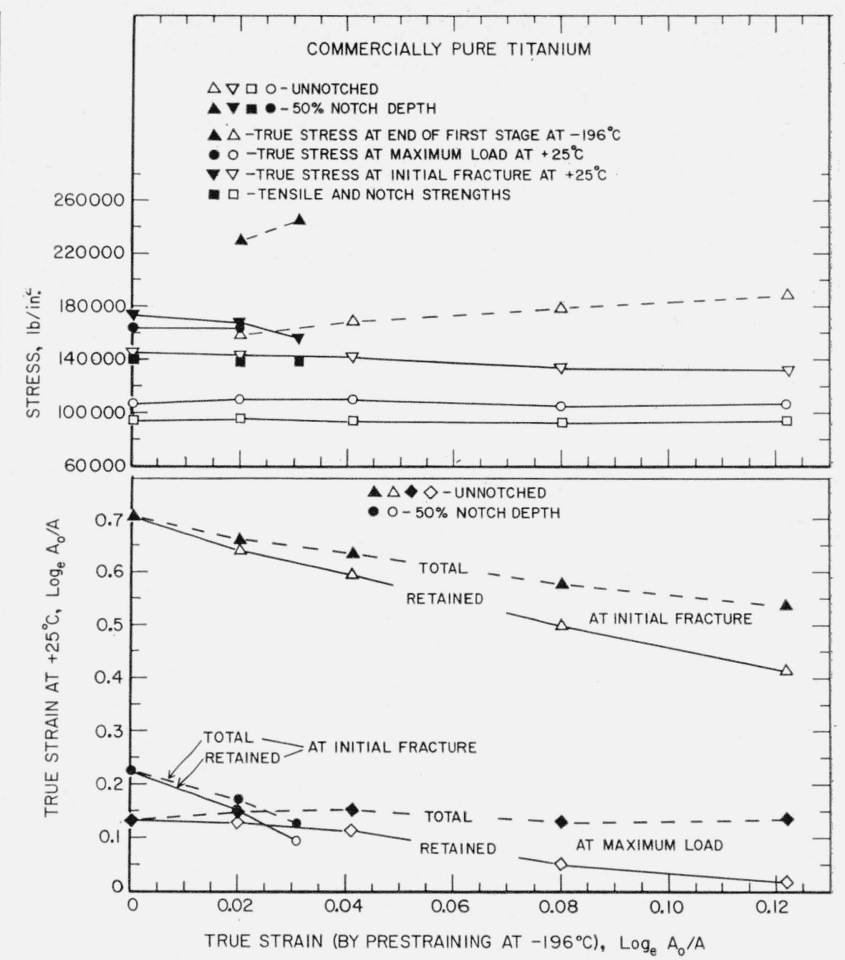

FIgure 25. Effect of prestraining in tension at $-196^{\circ} \mathrm{C}$ on the strength and ductility at $+25^{\circ} \mathrm{C}$ of unnotched and notched specimens of the titanium.
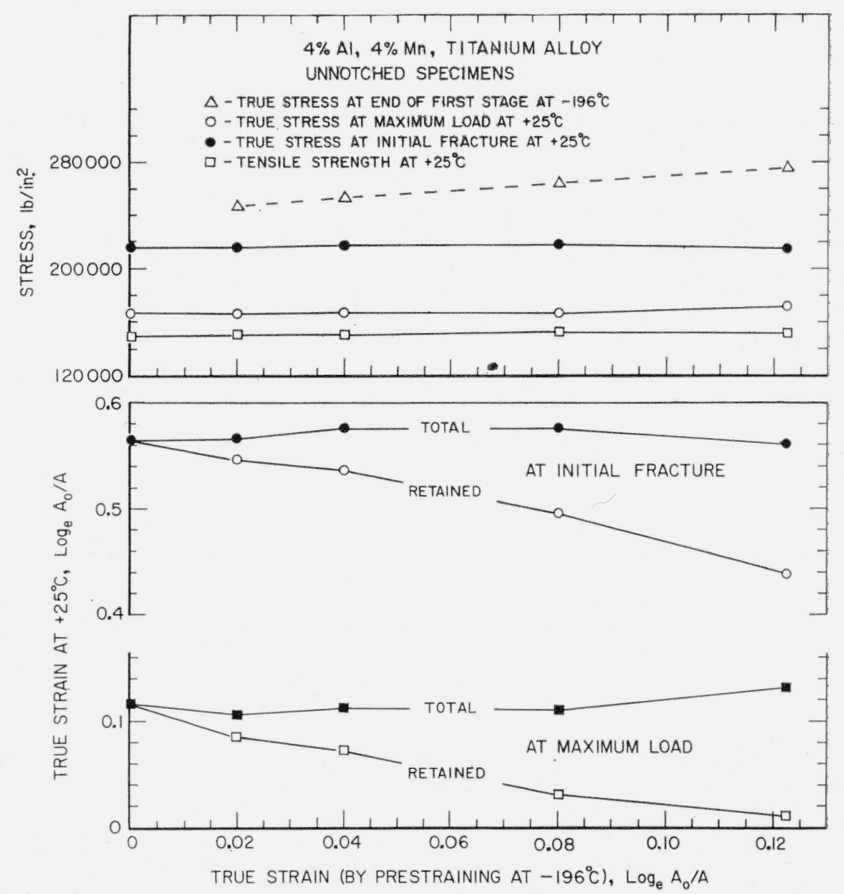

Figure 26. Effect of prestraining in tension at $-196^{\circ} \mathrm{C}$ on the strength and ductility at $+25^{\circ} \mathrm{C}$ of unnotched specimens of the alloy. 


\section{c. Ductility}

The effects of prestraining at $-196^{\circ} \mathrm{C}$ on the ductility of the titanium and the alloy at $+25^{\circ} \mathrm{C}$ are shown by the data as summarized in figures 25 and 26, respectively. The total true strains at maximum load at $+25^{\circ} \mathrm{C}$ of the unnotched specimens of both metals and the total true strain at initial fracture of the alloy were approximately independent of the prestrain. Thus, the retained true strains of these specimens decreased with an increase in the prestraining by amounts approximately equivalent to the prestrain. The total true strain at initial fracture of both unnotched and notched specimens of the titanium (fig. 25) decreased continuously with increase in the prestrain. The decrease in the retained true strain at initial fracture of the unnotched specimens at $+25^{\circ} \mathrm{C}$ was approximately twice the prestrain at $-196^{\circ} \mathrm{C}$. The effect of the prestrain at $-196^{\circ} \mathrm{C}$ of the notched specimens of titanium on their ductility at $+25^{\circ} \mathrm{C}$ was very pronounced; the retained true strain at initial fracture was decreased by an amount approximately equal to 4 times the prestrain.

The pronounced difference in the effect of prestraining at $-196^{\circ} \mathrm{C}$ on the total ductility (also retained ductility) at $+25^{\circ} \mathrm{C}$ of the unnotched specimens of the titanium and the alloy indicates that the effect of temperature on the mechanisms of deformation is considerably greater for the titanium than for the alloy. No information is readily available on the specific deformation mechanisms of the 4-percent-Al, 4-percent-Mn, titanium alloy either at room temperature or at $-196^{\circ} \mathrm{C}$. However, results obtained in studies on the mechanisms of deformation for titanium at different temperatures have been reported in several papers [6 to 10]. These studies show that the tensile deformation of titanium at $-196^{\circ} \mathrm{C}$ occurs mainly by twinning, and also by some slip on the prismatic planes. The amount of twinning, in general, decreased with increase in the temperature of deformation. The tensile deformation at $+25^{\circ} \mathrm{C}$ occurs by twinning, and by slip on the prismatic, pyramidal, and basal planes $[6,7$, and 9].

The ductility behavior of the titanium specimens in the two-stage tests of $-196^{\circ} \mathrm{C}$ and $+25^{\circ} \mathrm{C}$, respectively, may be partially explained on the basis of the above mechanisms of deformation and a tentative hypothesis as follows: Prestraining the specimens at $-196^{\circ} \mathrm{C}$, in which the slip is restricted to the prismatic planes, exhausts a greater proportion of the total available movement of dislocations along the prismatic planes than the same amount of prestrain under the more ductile condition at $+25^{\circ} \mathrm{C}$, in which the slip is distributed among the prismatic, pyramidal, and basal planes. Thus, the subsequent movement of dislocations along the prismatic planes in the second stage of the test at $+25^{\circ} \mathrm{C}$ is more restricted for the specimens prestrained at $-196^{\circ} \mathrm{C}$ than for those with the same prior strain at $+25^{\circ} \mathrm{C}$. This embrittlement of the titanium increases with an increase in the prestrain at $-196^{\circ} \mathrm{C}$ and results in a decrease in the total and retained true strains at initial fracture at $+25^{\circ} \mathrm{C}$. The hypothesis assumes that the initiation of the fracture of the titanium at $+25^{\circ} \mathrm{C}$ is mainly dependent upon the exhaustion of dislocation movements on the prismatic planes.

It may be inferred from the apparent insensitivity of the ductility at $+25^{\circ} \mathrm{C}$ of the titanium alloy specimens to the temperature during the prior straining (prestraining to selected strains at $-196^{\circ} \mathrm{C}$ or testing in a single stage test at $+25^{\circ} \mathrm{C}$ ) that the deformation mechanisms of the alloy are not very different at $-196^{\circ}$ and $+25^{\circ} \mathrm{C}$. However, this inference must be considered with reservation due to the limited experimental data and lack of information on the specific deformation mechanisms for the alloy.

\section{Summary}

A study was made of the effect of the prior straintemperature history on the tensile behavior of unnotched and notched specimens $\left(60^{\circ}\right.$ notch angle, 0.05-in. root radius, 0.35 -in. diameter at root of notch and selected notch depths) of initially annealed commercially pure titanium and initially annealed 4-percent-Al, 4-percent-Mn, titanium alloy. Three series of two-stage tension tests were made: In two series, the specimens were extended at $+25^{\circ} \mathrm{C}$ to selected strains up to true strains of 0.08 or 0.12 and then to fracture at $(1)-196^{\circ} \mathrm{C}$ or $(2)+100^{\circ} \mathrm{C}$; in the other series, the specimens were extended at $-196^{\circ} \mathrm{C}$ to selected strains up to true strains of 0.03 or 0.12 and then to fracture at $+25^{\circ} \mathrm{C}$. It was not feasible to conduct this series of tests on the notched specimens of the alloy due to the very limited ductility of these specimens at $-196^{\circ} \mathrm{C}$.

The resistance to deformation of both the unnotched and notched tensile specimens of each metal at a selected temperature, in general, was nearly independent of the temperature of the prior deformation. The true stress-true strain data obtained in the single-stage tests and in the two-stage tests on the unnotched specimens indicate that the total work hardening (strain hardening, strain aging or recovery) of each metal during the extension to a selected strain is nearly the same at $-196^{\circ},+25^{\circ}$, and $+100^{\circ} \mathrm{C}$.

The tensile or notch strength and the true stress at initial fracture of the unnotched and notched specimens of the titanium and the alloy at $-196^{\circ}$, $+25^{\circ}$ or $+100^{\circ} \mathrm{C}$, in general, were independent of the amount of prestraining. An exception to this general trend was observed at $-196^{\circ} \mathrm{C}$ with the deep-notched specimens of the alloy that were prestrained at $+25^{\circ} \mathrm{C}$ to true strains above 0.04 ; the notch strength and true stress at initial fracture of these specimens decreased with increase in the prestraining. However, the decrease in these values can be attributed directly to the very small retained ductility of the specimens at $-196^{\circ} \mathrm{C}$.

The retained ductility of the unnotched and 
notched specimens of the titanium and the alloy at $-196^{\circ}$, $+25^{\circ}$, and $+100^{\circ} \mathrm{C}$ depended upon the prior strain-temperature history of the specimens. The retained true strain at initial fracture of the unnotched specimens of both metals at $-196^{\circ}$ or $+100^{\circ} \mathrm{C}$ and the alloy at $+25^{\circ} \mathrm{C}$, generally decreased by amounts approximately equal to the prestrain. However, prestraining the unnotched specimens of the titanium at $-196^{\circ} \mathrm{C}$ decreased the retained true strain at initial fracture at $+25^{\circ} \mathrm{C}$ by amounts approximately equal to twice the prestrain.

The prestraining of notched specimens of both metals also had a deleterious effect on their ductility. The retained true strain at initial fracture at $-196^{\circ}$ or $+100^{\circ} \mathrm{C}$ decreased with increase in the prestraining at $+25^{\circ} \mathrm{C}$. Moreover, the retained true strain at initial fracture at $+25^{\circ} \mathrm{C}$ of the notched specimens of the titanium was reduced greatly by prestraining at $-196^{\circ} \mathrm{C}$; prestraining to a small true strain of 0.02 or 0.03 decreased the retained true strain at initial fracture by an amount nearly equal to 4 times the prestrain.

The results obtained in this investigation indicate that neither the annealed commercially pure titanium nor the annealed 4-percent-Al, 4-percent-Mn, titanium alloy are subject to "rheotropic embrittlement" as the prestraining of the tensile specimens at $+25^{\circ} \mathrm{C}$ resulted in a decrease instead of an increase in their retained ductility at $-196^{\circ} \mathrm{C}$.

\section{References}

[1] E. J. Ripling and W. M. Baldwin, Jr., Rheotropic embrittlement of steel. Trans. Am. Soc. Metals 43 , 778 (1951).

[2] G. W. Geil and N. L. Carwile, Effect of strain-temperature history on the flow and fracture of ingot iron at low temperatures, J. Research NBS 48, 399 (1952) RP2329.

[3] G. W. Geil and N. L. Carwile, Some effects of low temperatures and notch depth on the mechanical behavior of an annealed commercially pure titanium, J. Research NBS 59, 215 (1957) RP2790.

[4] G. W. Geil and N. L. Carwile, A reduction-of-area gage for use at low temperatures, J. Research NBS 43, 527 (1949) RP2044.

[5] G. W. Geil and N. L. Carwile, Tensile properties of ingot iron at low temperatures, J. Research NBS 45, 129 (1950) RP2119.

[6] F. D. Rosi, F. C. Perkins, and L. L. Seigle, Mechanism of plastic flow in titanium at low and high temperatures, Trans. Am. Inst. Mining Met. Engrs. 206, 115 (1956)

[7] E. A. Anderson, D. C. Jillson, and S. R. Dunbar, Deformation mechanisms in alpha titanium, Trans. Am. Inst. Mining Met. Engrs. 197, 1191 (1953).

[8] C. J. McHargue and J. P. Hammond, Deformation mechanisms in titanium at elevated temperatures, Acta Met. 1, 700 (1953).

[9] A. T. Churchman, The slip modes of titanium and the effects of purity on their occurrence during tensile deformation of single crystals, Proc. Royal Soc. (London) 「A] 226, 216 (1954).

「10] A. T. Churchman, The yield phenomena, kink bands and geometric softening in titanium crystals, Acta Met. 3, 22 (1955).

Washington, April 17, 1958. 